\title{
Latvijas Republikas Satversmes 4. panta pirmā teikuma "Valsts valoda Latvijas Republikā ir latviešu valoda" zinātnisko komentāru papildinājums
}

\section{Supplement to Scientific Comments of the First Sentence of Article 4 of the Satversme of the Republic of Latvia "The Official State Language in the Republic of Latvia is the Latvian Language"}

\author{
Dr. iur., profesors Ringolds Balodis \\ ORCID: 0000-0002-7139-9907 \\ Latvijas Universitāte, Juridiskā fakultāte, Latvija \\ Ringolds.Balodis@lu.lv
}

\section{Abstract}

The Latvian language is an essential element of constitutional identity of the Republic of Latvia, without which the Latvian constitutional system and the system of Constitution cannot be imagined, as such. Since 2021, the Official Language Day on 15 October has been celebrated. According to the President of Latvia Egils Levits the Official Language Day may serve as another opportunity to spread awareness and promote the use of the Latvian language as one of the main constitutional values of our state and nation. The Official Language Day is a meaningful contribution to the future tradition of celebrating the official language across society.

The current study focuses on the issue of the official language in Latvia and its importance from the perspective of constitutional law. The experience of the Republic of Latvia is divided into two periods. The first - covers the period 1918-1940, when it was interrupted by the Soviet occupation. Consequently, after the restoration of independence in 1990, the second period can be defined: 1990-currently. If during the pre-war period the Latvian language was only enshrined in law, during the second period the official language has been enshrined in the Constitution (Satversme). The official language of the Latvian Constitution is specified in Section 4. The given 
"Valsts valoda Latvijas Republikā ir latviešu valoda" zinātnisko komentāru papildinājums

article is designed to supplement the scientific comments of Section 4, which was issued in 2014.

Keywords: Constitution (Satversme), Latvian language, official language, language policy, national minorities.

\section{levads}

Latviešu valoda ir valsts pārvaldes oficiālā valoda Latvijas valstī kopš Latvijas Republikas proklamēšanas, lai gan tajā pašā laikā parlamentā, pašvaldībās, par privāto sfēru nemaz nerunājot, faktiski pastāvēja trīsvalodība (latviešu, vācu un krievu valoda), kā arī bija latgaliešu izloksnes brīva lietošana Latgalē. Tikai pēc tam, kad 1932. gadā Ministru kabinets izdeva "Noteikumus par valsts valodu", kuriem bija likuma spēks, var runāt par valsts valodas tiesisku regulējumu valsts līmenī, kā arī likumiskiem nosacījumiem mazākumtautību valodu lietošanai.

Latviešu valodas un mazākumtautību valodu jautājumam ir visai gara vēsture. Piemēram, Tautas padomes valdošais viedoklis bija šāds: vispirms konstitucionāli jānosaka valsts valodas statuss latviešu valodai un tikai pēc tam jānoregulē mazākumtautìbu valodu lietošanas nosacījumi. Šis bija galvenais arguments mazākumtautību valodu likuma noraidǐšanai Tautas padomē (1919).

Savukārt Satversmes sapulce valsts valodas klauzulu ietvēra Satversmes otrās daḷas projekta 115. pantā, kura pirmajā teikumā (virsteikumā) paredzēja latviešu valodas kā valsts valodas statusu, bet otrajā dạ̦ā paredzēja speciāla likuma pieņemšanu par mazākumtautību valodām. Šis jautājums Satversmes sapulcei izrādijjās neatšḳetināms Gordija mezgls, kurā par galveno šḳērsli izrādījās nevis mazākumtautību prasības, bet paša konstitucionālā likumdevēja ieskats par latviešu valodas lietošanu, kas nepieḷāva mazākās konstitucionālās atkāpes no literārās latviešu valodas.

Līdz ar padomju okupāciju, latviešu valoda kḷva par mazākumtautību valodu, kuru, tāpat kā citu PSRS tautu valodas, pakḷāva rusifikācijas politikai. PSRS sabrukuma priekšvakarā - pagājušã gadsimta 80 . gadu beigās - latviešu nacionālā atmoda ar pretenzijām pēc autonomijas nāca roku rokā ar lingvistiskām prasībām. 1988. gada 6. oktobrī Latvijas Padomju Sociālistiskās Republikas (turpmāk - LPSR) Augstākā padome pieñēma vēsturisku lēmumu par valsts valodu, un jau pēc pusgada tika veikti grozījumi LPSR Konstitūcijā un pieņemts LPSR Valodu likums. Tà 1. pantā bija noteikts, ka saskaņā ar Latvijas PSR Konstitūciju valsts valoda ir latviešu valoda. Tas gan nenozīmē, ka šis tiesību akts bija orientēts uz divvalodības novēršanu, šis regulējums drīzāk uzskatāms par latviešu valodas saglābšanas pasākumu kopumu. Likums aizsāka ilgstošu valodu hierarhijas main̦as procesu par labu latviešu valodai un bija priekšvēstnesis tām izmaiņām, kas sekoja pēc Neatkarības deklarācijas pieñemšanas (1990). Grozỉjumi LPSR Valodu likumā (1992) būtiski mainīja Valodu likumu, un tie patiesībā jāuzskata par jaunu likumu, kas orientēts uz latviešu valodas dominanci valsts pārvaldē un publiskajā telpā. 
"Valsts valoda Latvijas Republikā ir latviešu valoda" zinātnisko komentāru papildinājums

1995. gada novembrī tika aizsākts jauna Valsts valodas likuma veidošanas posms, kas noslēdzās vien pēc četru gadu ilga dinamiska likumdošanas procesa. Likumprojekts tika skatīts vairākās Saeimās, un tas pārdzīvoja starptautisko ekspertu skarbu kritiku un Valsts prezidenta veto. Šì likumprojekta liktenis ir neparasts, un Saeimas likumdošanas aktu arhīvā parastās vienas dokumentu mapītes vietā tas aizṇem palielu plauktu ar vairākiem desmitiem mapju. Kad ar likuma spēkā stāšanos (2000) spēku zaudēja iepriekšējais Valodu likums, daudzi politiḳi jutās pamatīgi vīlušies un atzina, ka salīdzinājumā ar iepriekšējo šis likums sanācis "krietni maigāks" un "vājinot latviešu valodas pozīcijas", līdz ar to "mazinājusies ir latviešu valodas juridiskās aizsardzības kvalitāte". Nākas secināt, ka centieni izstrādāt jaunu likumu, nevis uzlabot veco, bija liela stratēgiska kḷūda. Latviešu valoda kā valsts valoda tika nostiprināta arī Satversmē (1998). Valodas jautājums nezaudēja savu sabiedriski politisko aktualitāti. Tika organizēts "valodas referendums" par krievu valodu kā otru valsts valodu (2012). Politiskās elites atbilde bija tautas nobalsošanas prasību sarežǵgišana un pastiprināšana, kas referendumus padara par vien teorētisku iespējamību.

Pateicoties Satversmes grozījumiem, Satversmes tiesas un Augstākās tiesas judikatūrai, kā arī, protams, tiesību zinātnieku rakstiem, kuros attīstītas tiesību doktrīnas atziņas, Satversme, par spìti tās respektablajam vecumam, atsevišķu normu senajam skanējumam un formulējumu lakonismam, joprojām saglabā "jaunību", ${ }^{1}$ un tai ir spēja regenenerēties arī visaptverošas datortehnikas un interneta laikmetā. Satversmes zinātniskie komentāri kā sistematizēts, metodoloǵiski veidots un padziḷināts pētniecisks materiāls, bez šaubām, ir ieskaitāms šai Satversmes “jaunības saglabāšanas līdzekḷu” komplektā. Lai gan Latvijas tiesību sistēma ir neliela, tomēr tā atrodas pastāvīgā attīstībā, tāpēc vien dažus gadus pēc atsevišḳu komentāru nodaḷu izdošanas tās lasāmas tikai kopā vai, ḷoti vēlams, - kopā ar jaunākajām tiesu atziṇām un zinātniskām publikācijām. Piemēram, Satversmes 4. panta komentāru² ieteicams lasìt kopā ar Satversmes tiesas 2015. gada 2. jūlija spriedumu lietā Nr. 2015-01-01, ${ }^{3}$ savukārt Satversmes 15. panta komentāru ${ }^{4}$ izlasot, vajadzētu ieskatīties arī Satversmes tiesas 2021. gada 12. marta spriedumā lietā Nr. 2020-37-0106, Satversmes 21. panta komentāru ${ }^{5}$

${ }^{1}$ Gehtmane-Hofmane, I. (2021). Satversmes komentāri - zinātnisks traktāts ar praktisku pielietojumu. Zinātṇu Vēstnesis. 3(608), 29.03.2021.; Balodis, R. (2020). Lìdz ar Satversmes II nodal̦as komentāru izdošanu noslēdzies Satversmes zinātnisko komentāru projekts. Jurista Vārds. 36(1146), 08.09.2020.

2 Druviete, I., Kārkliṇa, A., Kusiṇš, G., Pastars, E., un Pleps, J. (2014). Satversmes 4. panta komentārs. No: Latvijas Republikas Satversmes komentāri. Ievads. I nodaḷa. Vispārējie noteikumi. Aut. kol. prof. R. Baloža zin. vad. Rīga: Latvijas Vēstnesis, 295-330.

${ }^{3}$ Satversmes tiesas 2015. gada 2. jūlija spriedums lietā Nr. 2015-01-01, secinājumu daḷas 11.4 un 15.2 punkts.

${ }^{4}$ Kusiņš, G. (2020). Satversmes 15. panta komentārs. No: Latvijas Republikas Satversmes komentāri. II nodal̦a. Saeima. Aut. kol. prof. R. Baloža zin. vad. Rīga: Latvijas Vēstnesis, 243-351.

${ }^{5}$ Pleps, J. (2020). Satversmes 21. panta komentārs. No: Latvijas Republikas Satversmes komentāri. II nodal̦a. Saeima. Aut. kol. prof. R. Baloža zin. vad. Rīga: Latvijas Vēstnesis, 343-363. 
"Valsts valoda Latvijas Republikā ir latviešu valoda" zinātnisko komentāru papildinājums

lasot, vēlams ieskatīties Satversmes tiesas 2019. gada 23. decembra spriedumā lietā Nr. 2019-08-01, Satversmes 99. panta komentāru ${ }^{6}$ noteikti vajadzētu skatìt kopā ar Satversmes tiesas 2011. gada 18. marta spriedumu lietā Nr. 2010-50-03 un Satversmes tiesas 2018. gada 26. aprịla spriedumu lietā Nr. 2017-18-01, bet Satversmes 110. panta komentārs ${ }^{7}$ ir jāaplūko ne tikai kopā ar Satversmes tiesas 2020. gada 11. novembra spriedumu lietā Nr. 2019-33-01, bet noteikti arī ar Satversmes tiesas tiesneša Alda Laviṇa atsevišḳo viedokli ${ }^{8}$ šai lietā. Judikatūra, protams, sniedz svarīgu informāciju par tiesību normu piemērošanas praktiskajiem aspektiem, ${ }^{9}$ taču uz vietas nestāv arī konstitucionālo institūciju veiktā interpretācija, kas dažos gadỉjumos ir pat visai būtiska. ${ }^{10}$

Par impulsu šã raksta tapšanai kalpoja žurnāla "Jurista Vārds" redakcijas lūgums sagatavot nelielu juridisku eseju par valsts valodu, sagaidot Satversmes simtgadi. Pēc fundamentālas iegremdēšanās valodas tematikā kḷuva skaidrs, ka daudz kas samērā nozīmīgs Satversmes komentāros ir palicis nepateikts. Tomēr šis raksts nav uzskatāms kā "komentārs par komentāru" vai "atsevišḳs viedoklis" par Satversmes 4. panta zinātnisko komentāru. 2014. gadā izdotais zinātniskais komentārs ir rūpīgi izstrādāts un pārdomāts, ${ }^{11}$ taču pat tik apjomīgs darbs, ko veica ievērojams autoru kolektīvs, nespēj pilnībā aptvert visu valodas sadal̦as genēēi. Ar saviem papildinājumiem vēlos paplašināt šo komentāru ar jauniem, neaplūkotiem vai nepietiekami dziḷi analizētiem faktiem un apsvērumiem. Papildinājumi padziḷina zinātnisko komentāru skatījumu un sniedz skaidrāku pirmā un nedaudz arī otrā neatkarības laika valsts valodas tiesiskā regulējuma attīstību. Jautājums par valsts valodu un tās aizsardzību, kā arī normatīvo regulējumu ir viens no būtiskajiem nacionālas valsts pamatjautājumiem. Satversmes 4. panta komentētājs, Latvijas Universitātes Juridiskās fakultātes Tiesību teorijas un vēstures katedras vadītājs docents Jānis Pleps pamatoti ir norādījis, ka ikvienam tiesību elementam, ar kuru mēs šodien

${ }^{6}$ Balodis, R. (2011). Satversmes 99. panta komentārs. No: Latvijas Republikas Satversmes komentāri. VIII nodal̦a. Cilvēka pamattiesības. Aut. kol. prof. R. Baloža zin. vad. Rīga: Latvijas Vēstnesis, 319-342.

${ }^{7}$ Dupate, K., Reine, I. (2011). Satversmes 110. panta komentārs. No: Latvijas Republikas Satversmes komentāri. VIII nodal̦a. Cilvēka pamattiesības. Aut. kol. prof. R. Baloža zin. vad. Rìga: Latvijas Vèstnesis, 571-510.

${ }^{8}$ Satversmes tiesas tiesneša Alda Laviṇa atsevišḳās domas lietā Nr. 2019-33-01 "Par Darba likuma 155. panta pirmās daḷas atbilstību Latvijas Republikas Satversmes 110. panta pirmajam teikumam”.

${ }^{9}$ Satversmes tiesas 2012. gada 1. novembra spriedums lietā Nr. 2012-06-01, 7.2 punkts.

${ }^{10}$ Piemēram, Valsts prezidents Egils Levits ir ievērojami paplašinājis Satversmes normā noteikto Valsts prezidenta aizvietotāju loku, vienlaikus mainot arī pašu prombūtnes izpratni (runa ir par tiesiski nenoteiktā jēdziena "vai citādi kavēts pildīt savu amatu" izpratni), tādējādi mūsdienīgojot kopš Satversmes pieṇemšanas brīža negrozìto Satversmes normu (sk. Valsts prezidenta Egila Levita 2019. gada 5. augusta paziņojumu Nr. 3 "Par Latvijas Republikas Satversmes 52. panta piemērošanu").

${ }^{11}$ Matule, S. (2014). Satversmes komentāros padziḷināti izvērsti arī valsts pamati. Jurista Vārds. 46(849), 08.09.2014. 
darbojamies, vienmēr klātesoša ir vēstures un nākotnes perspektīva. Saskaroties ar kādas tiesību normas iztulkošanu, būtiski ir ṇemt vērā vēsturiskā likumdevēja gribu un vēsturisko kontekstu, kurā norma radusies un attīstījusies, ${ }^{12}$ un tieši par to šai komentāra papildinājumā arī ir runa.

\title{
Latvijas Republikas Satversmes 4. panta komentāra papildinājums ${ }^{13}$ par B daḷas (Panta ǵenēze) pirmo sadaḷu (Karoga un valsts valodas regulējums pagaidu satversmēs)
}

\section{Valsts valoda Latvijas Republikā ir latviešu valoda. Latvijas karogs ir sarkans ar} baltu svitru.

\begin{abstract}
"Latvijas pagaidu satversmēs valsts karogs un valsts valoda konstitucionāli nebija reglamentēta. Ar pagaidu satversmju starpniecību valsts dibinātāji risināja citus aktuālos konstitucionālās politikas jautājumus. Savukārt gan valsts karoga krāsas, gan arī latviešu valoda kā valsts valoda tika uztvertas kā aksiomas, kuru papildu deklarēšana pagaidu satversmēs nebija nepieciešama. Kā Latvijas Tautas padomē norādījis K. Paul̦uks: "Visas Tautas padomes frakcijas atzina, ka Latvijā latviešu valoda ir valsts valoda." Zīmīga situācija par pašsaprotamu lietu izpratni vērojama Latvijas Tautas padomes 1919. gada 27. augusta sēdē, kurā tika izskatīts likums par valodu tiesībām. Debatējot par šo likumprojektu, tika izteiktas iebildes, jo tajā neesot norādīts, ka latviešu valoda ir valsts valoda. Viens no komisijas locekḷiem, skaidrojot situāciju, norādīja, ka tas notika "uz komisijas latviešu tautības locekḷu priekšlikumu, kas ieskatīja, ka tā nav mūsu darīšana, pašu par sevi saprotamu lietu jums vēl sevišḳi apstiprināt"."14
\end{abstract}

Arī Satversmes teksts tika izstrādāts latviešu valodā.

"Satversme ar savu pastāvēšanu apliecināja tautas gribu un izvēli savas valsts pamatus pasludināt latviešu valodā, kas ir neatṇemama konstitucionāla vērtība, kas iekḷauj savas tautas domāšanas stilu, pasaules uzskatu un apvieno nāciju." ${ }^{15}$

Tādēḷ par pilnīgi pamatotu atzīstams uzskats, ka "valoda, kurā konstitūcija tiek pienemta, ir uzskatāma par valsts valodu". ${ }^{16}$

"Satversmes komisijas sagatavotais Satversmes 115. pants paredzēja: Latviešu valoda ir valsts valoda. Mazākuma tautību piederīgiem ir garantēta viṇu valodas brīva lietošana kā runā, tā arī rakstos. Kādas mazākuma tautību valodas un cik tālu pielaižamas valsts pašvaldības un tiesu iestādēs, noteic seviškss likums.

\footnotetext{
12 Pleps, J. (2021).Vēstures nozìme tiesībnieka darbā. Jurista Vārds. 32(1194), 10.08.2021.

${ }^{13}$ Druviete, I., Kārkliṇa, A., Kusiṇš, G., Pastars, E., Pleps, J. (2014). Satversmes 4. panta komentārs. No: Latvijas Republikas Satversmes komentāri. Ievads. I nodaḷa. Vispārējie noteikumi. Aut. kol. prof. R. Baloža zin. vad. Rīga: Latvijas Vēstnesis, 295-330.

14 Turpat, 298.

15 Turpat, 299.

16 Turpat.
} 


\section{Ringolds Balodis. Latvijas Republikas Satversmes 4. panta pirmā teikuma \\ "Valsts valoda Latvijas Republikā ir latviešu valoda" zinātnisko komentāru papildinājums}

Latvijas Satversmes sapulcē šā panta piedāvājums izraisīja plašas diskusijas, kas bija saistīts ar latgaliešu rakstu valodas jautājumu. Vairāki Satversmes sapulces locekḷi bija iesnieguši priekšlikumu noteikt, ka Latgales apgabalā par oficiālu valodu tiek atzìta latgaliešu izloksne [..]." 17

“Tā kā Satversmes II daḷu nepieṇēma, valsts valodas regulējums tika saglabāts zemāka juridiskā spēka tiesību aktu līmenī. Latviešu valodas pozīcijas pilnā mērā nostiprināja 1935. gada Likums par valsts valodu." 18

Tautas padome (turpmāk - TP vai priekšparlaments) 1918. gada 6. decembrī pieñēma pagaidu nolikumu "Par Latvijas tiesām un tiesāšanās kārtību", ${ }^{19}$ kurā kā "darīšanu valoda tiesās un tiesu iestādēs" tika noteikta latviešu valoda, vienlaikus dodot likumisku pamatu arī krievu un vācu valodas brīvai lietošanai. ${ }^{20}$ Šis solis iezīmēja sākumu faktiskai trīsvalodỉbai un jaunās valsts lingvistiskai tolerancei attiecībā uz lielāko mazākumtautību valodu lietošanu. Ielūkojoties tā laika statistikā, ir redzams visai izteikts krievu, taču ne vācu mazākumtautības īpatsvars salīdzinājumā ar citām mazākumtautībām. Saskaṇā ar 1920. gada statistikas datiem Latvijā bija 1596131 iedzīvotājs, no tiem 72,8 \% bija latvieši. Starp lielākajām mazākumtautībām ir minēti lielkrievi un baltkrievi - 12,6\%, ebreji - 5\%, vācieši - 3,6\% un poḷi - 3,4\%. ${ }^{21}$ Iedzìvotāji gan nebija vienmērīgi izvietojušies visā valsts teritorijā - dati liecina, ka latviešu skaits laukos vietām sasniedza pat $90 \%$ un vairāk, tomēr pilsētās šī proporcija bija pilnīgi cita. Tā Rīgā latviešu bija vien nedaudz vairāk par pusi jeb 55,12\%. Līdzīga situācija bija arī Liepājā - 52,29\%, bet Latgales pilsētās, piemēram, Rēzeknē latviešu bija vien 19,26\%, Daugavpilī pat vēl mazāk - 5,15\% (!). ${ }^{22}$ L,oti neviendabīgs bija mazākumtautību iedzīvotāju izvietojums dažādos reǵionos. Vācu valodas izplatība plašāka bija Kurzemes pusē, bet krievu valodas - Latvijas dienvidaustrumos. Ir jāatzīst, ka Latvijā pagājušā gadsimta

${ }^{17}$ Druviete, I., Kārkliṇa, A., Kusiṇš, G., Pastars, E., Pleps, J. (2014). Satversmes 4. panta komentārs. No: Latvijas Republikas Satversmes komentāri. Ievads. I nodaḷa. Vispārējie noteikumi. Aut. kol. prof. R. Baloža zin. vad. Rīga: Latvijas Vēstnesis, 300.

18 Turpat, 301.

${ }^{19}$ Par Latvijas tiesām un tiesāšanās kārtību: Tautas padomes pagaidu nolikums. Pagaidu Valdības Vēstnesis. 1918. g. 14 (1.) decembris; Latvijas Pagaidu Valdības Likumu un Rīkojumu Krājums. 1, 15.07.1919.

${ }^{20}$ Svarīgi piebilst, ka šis Tautas padomes darbības otrajā mēnesī pieṇemtais nolikums, ar kuru Latvija pārṇēma Krievijas tiesu iekārtu, saglabājās arī pēc Latvijas Republikas Satversmes pieṇemšanas, jo balstījās uz Krievijas 1864. gada Tiesu iekārtas likumu (ar tā grozījumiem līdz 1917. gada 1. augustam), kas savulaik tika uzskatīts par labāko Eiropā. Sk. Krūmiṇa, V. (2013). Ievads Latvijas Republikas Satversmes VI nodalas komentāram: tiesu varas evolūcija Latvijā. No: Latvijas Republikas Satversmes komentāri. VI nodaḷa. Tiesa. VII nodaḷa. Valsts kontrole. Aut. kol. prof. R. Baloža zin. vad. Rìga: Latvijas Vēstnesis, 11-12.

${ }^{21}$ Skujenieks, M. (1925). Otrā tautas skaitīšana Latvijā. Rīga, 52. Citēts pēc: Sosāre, M. (1992). Valodu likumdošanas jautājumi Latvijas Republikas pastāvēšanas sākuma posmā. Latvijas Zinātṇu Akadēmijas Vēstis. A dal̦a, 4, 01.04.1992.

22 Turpat, 58. 
"Valsts valoda Latvijas Republikā ir latviešu valoda" zinātnisko komentāru papildinājums

20.-30. gados krustojās lielu tautu kultūras un politikas iespaids un liela iedzīvotāju daḷa prata vairākas valodas, ko īpaši var teikt par pilsētniekiem, kuri "lielā skaitā runāja divās, trīs un pat četrās valodās". ${ }^{23}$

Profesore Ina Druviete, kas ir arī viena no 4. panta komentētājām, savā publikācijā "Latvijas valodu politika Eiropas Savienības kontekstā" pamatoti norāda, ka pasaules vēsture ir arī nepārtrauktas valodu cīṇas vēsture (valodu darvinisms). Valodu kontakti, pēc zinātnieces ieskata, nozīmē valodu konfliktus, un valodu attiecībās vienmēr ir valdījusi un valdīs konkurence. ${ }^{24}$ Patiešām, Latvijā pirmajā (un vēlāk arī otrajā) neatkarības periodā par valodas statusu notika skarba politiskā cīṇa, kurā latviešu valoda ir izcīnījusi sev valsts valodas statusu.

Satversmes komentāros ir citēti divu TP delegātu - Latviešu zemnieku savienības frakcijas locekḷa Kārḷa Vilhelma Pauḷuka un Vācbaltiešu demokrātiskās partijas (DeutschBaltische Demokratische Partei) frakcijas un Nacionālo lietu komisijas priekšsēdētāja Paula Šìmaṇa - izteikumi 1919. gada 27. augusta sēdē. Ja Satversmes komentāros citētie izteikumi tiek atrauti no sēdes debates konteksta, tie var radìt nepareizu iespaidu par tā laika reālo situāciju jautājumā par latviešu valodu kā valsts valodu. Senās priekšparlamenta sēdes stenogramma spēcīgi ilustrē mazākumtautību un latviešu pārstāvju cīṇu, par ko iepriekš runā Ina Druviete. Latviešu valodai pienākošos vietu neviens neuzlūkoja per se. Krievu valoda bija impērijas valoda, bet vācieši Latvijā gadu simteṇiem bija elites statusā. Bijušo muižas zemnieku, mājkalpotāju, kučieru un strādnieku valodai pēkšṇa kḷūšana par valsts pārvaldes oficiālo valodu viniem vēl nebija arguments, lai necīnītos par krievu un vācu valodas privilēgijām. Šo aspektu labi raksturo TP 1919. gada 27. augusta sēdē barona Eduarda fon Rozenberga (pirmā Latvijas Republikas valsts kontroliera) teiktā runa, kuras fragments izsaka pašu šo domāšanas būtību (runāja vāciski): "Ja jūs, kungi, no mums prasāt latviešu valsts valodas prašanu, tad jūs prasāt no mums neiespējamo, jo šo valodu mēs, par nožēlošanu, nekad savās skolās neesam mācījušies. Bet jūs visi protat mūsu valodas, vai nu vāciski, vai krieviski, tādēḷ mēs no jums nekā neiespējama neprasām!"25

Zīmīgs ir Kārḷa Vilhelma Pauḷuka sēdē teiktais, kas citēts 4. panta Satversmes komentārā: "Visas Tautas padomes frakcijas atzina, ka Latvijā latviešu valoda ir valsts valoda." Sevišḳi tas ir nozīmīgs tāpēc, ka turpat viņš arī saka: "Ar šā likuma pieṇemšanu agrākie vispārīgie nosacỉjumi krīt nost, jo šis projekts satur speciālu noteikumu par valodu tiesībām. [..] Bet tas nav izpildāms. No mums minoritātes prasa to, ko mēs nevaram izpildit." 26

${ }^{23}$ Sosāre, M. (1992). Valodu likumdošanas jautājumi Latvijas Republikas pastāvēšanas sākuma posmā. Latvijas Zinātñu Akadēmijas Vēstis. A dal̦a, 4, 01.04.1992.

${ }^{24}$ Druviete, I. (1998). Latvijas valodu politika Eiropas Savienības kontekstā. Rīga: LU Latviešu valodas institūts, LZA Ekonomikas institūts, 147.

25 Tautas padomes 4. sesijas 8. sēdes 1919. gada 27. augustā stenogramma.

26 Turpat. 
"Valsts valoda Latvijas Republikā ir latviešu valoda" zinātnisko komentāru papildinājums

Izlasot Satversmes komentāros citēto Pauḷuka runas fragmentu, kurā viṇš runā par kādu agrāku vienošanos (nosacījumiem), rodas jautājums, par ko runā Pauḷuks un kāds tam sakars ar konkrēto TP sēdi? Atbilde meklējama Tautas padomes kompozīcijā (veidošanā) un nosacījumos par darba organizāciju (arī valodas lietošanu) priekšparlamentā. Sēdē tika skatìts Mazākumtautību valodu likuma (turpmāk - MVL) projekts, kas cieši saistīts ar latviešu valodas lietošanu. Mazākumtautību delegāti TP bija iesnieguši apspriešanai pirmajā lasijjumā MVL projektu. Tas bija izstrādāts TP Nacionālo lietu komisijā, un sēdē to komisijas vārdā prezentēja minētās komisijas priekšsēdētājs baltvācietis Pauls Šīmanis, kurš paziṇoja, ka uzstājas TP mazākumtautību vārdā un ka tās "[..] neprasa vairāk, kā tikai to, ka ierēdṇi prastu vēl citas valodas, lai neviens valsts pilsonis latviešu valodas neprašanas dēḷ netiktu ierobežots savās tiesībās".

Pret likumprojektu asi iestājās latviskās partijas, piemēram, Zemnieku savienība, kuras pārstāvis Pauḷuks MVL nodēvēja par "cittautībnieku programmu”, norādot, ka caur MVL minoritātes savām valodām faktiski prasa valsts valodas statusu un šādā veidā latviešu valodu kā valsts valodu cenšas apiet. Uz pārmetumu, ka MVL dīvainā kārtā netiek runāts par valsts valodu, Šìmanis teica, arī 4. panta komentārā citētos, zīmīgos vārdus, ka tas nav mazākumtautību pienākums par valsts valodu domāt... Ir skaidrs, ka baltvācieša, kas sēdē principiāli runāja tikai vācu valodā, paustais ir vien politiska atrunāšanās, jo Pauḷuka teiktajā bija liela dạ̦a taisnības. Kā var pieņemt likumu par valodu lietošanu Latvijas valstī, ja tajā nav iestrādāts valsts valodas noregulējums?

Lai arī MVL nav saglabājies, sēdes stenogrammā ir fiksēti tā svarīgākie principi. Pirmkārt, likumprojekta pamatprincips bija "dažādās Latvijas vietās dažādām valodām dažādas tiesības".

Otrkārt, no stenogrammmas var saprast būtisku MVL ietvertu algoritmu, kas bija sasaistìts ar attiecīgā valsts administratīvā reǵiona minoritāšu apdzīvotības blīvumu. Tā, piemēram, ja pilsētā 20 \% vai attiecīgā pagastā dzīvo 50 \% mazākumtautības iedzīvotāju, tad minoritātes valoda bauda tur valsts valodas statusu. No Mazākumtautību valodu likuma projekta izrietēja īpašas tiesības vācu valodai pilsētās valsts centrālajā dạ̣ā, bet krievu valodai sevišḳs statuss Latgalē un vēl četrās valsts pilsētās.

Satversmes komentāros pamatoti ir teikts, ka, aizstāvot MVL projektu, par argumentu norādīts, ka "komisijas latviešu tautības locekḷi" ir atbalstijušsi MVL. ${ }^{27}$ Patiešām, šāds apgalvojums bija, un, visticamāk, tas izraisīja pamatīgu politisku traci. Latviešu pārstāvji TP Nacionālo lietu komisijā taisnojās, ka darbs tajā galvenokārt noticis svešvalodā, bez vinu aktĩvas iesaistes $u$. tml. Tam nekavējoši sekoja Latviešu zemnieku savienības frakcijas paziṇojums, ka tā atsauc savus pārstāvjus no Nacionālo lietu komisijas, to vietā nozīmējot citus. Viens no atsauktajiem bija arī dzejnieks Kārlis Skalbe, kuru kaunināja, -

${ }^{27}$ Druviete, I., Kārkliṇa, A., Kusiṇš, G., Pastars, E., Pleps, J. (2014). Satversmes 4. panta komentārs. No: Latvijas Republikas Satversmes komentāri. Ievads. I nodaḷa. Vispārējie noteikumi. Aut. kol. prof. R. Baloža zin. vad. Rīga: Latvijas Vēstnesis, 298. 
"Valsts valoda Latvijas Republikā ir latviešu valoda" zinātnisko komentāru papildinājums

kā viņš, tik pārliecināts latviešu patriots būdams, būtu varējis apstiprināt pret latviešu valodu vērstu likumprojektu. ${ }^{28}$

1919. gada 27. augusta debates par MVL bija pirmā nopietnā diskusija TP par valsts valodu Latvijas valstī. Latgaliešu delegātu ieskatā MVL projekts esot "Bābeles torña būvēšana". ${ }^{29}$ Debates noslēdzās ar Pauḷuka diplomātisko viedokli, ka valodu jautājums nav priekšparlamenta kompetencē. TP tomēr esot "kārtības nodibināšanai", bet valodas jautājums esot jāatstāj Satversmes sapulces ziṇā. MVL projekts tika noṇemts no dienaskārtības. Dažus mēnešus pēc tikko aplūkotajām debatēm kā savdabīga atbalss sekoja Tautas padomes kārtības ruḷla grozỉjums (38. pants), ar kuru latviešu valoda ieguva apzīmējumu "valsts valoda". Zìmīgi, ka jaunais regulējums piel̦āva jebkādu tulkošanu TP sēdes laikā tikai uz krievu, bet ne uz vācu valodu. ${ }^{30}$

Atgriežoties pie jautājuma par aplūkotajās debatēs Pauḷuka minēto vienošanos attiecībā uz latviešu valodu kā valsts valodu, ir jāieskatās TP veidošanās pamatprincipos.

TP bija nevēlēts, revolucionāri pašorganizēts pagaidu veidojums, kas tika radīts valsts izveidošanai. Latviešu politiskās organizācijas, dibinot TP, nostiprināja šādu apṇemšanos: "Pie Latvijas Tautas Padomes piedalās ar saviem deputātiem: a) politiskas partijas, b) nacionālās minoritātes un c) tie Latvijas novadi, t. i., Kurzeme un Latgale, kuros šimbrī̌̌am nepastāv politiskas partijas". ${ }^{31}$

Viens no Tautas padomes dibinātājiem Spricis Paegle, kas bija piedalījies arī TP dibināšanas sēdē 1918. gada 17. novembrī, norādīja, ka, TP dibinot, tika lemts $20 \%$ no kopējā TP locekḷu skaita atvēlēt nacionālajām minoritātēm ("pa visām tautībām kopā"). ${ }^{32}$ Šo apgalvojumu zināmā mērā apstiprina arī kāds cits tā laika notikumu aculiecinieks Ādolfs Klīve, kura atmiṇās var lasìt, ka Kārlis Ulmanis, kas bija TP īstenais veidotājs un arhitekts, "nacionālām minoritātēm rezervēja pārstāvību proporcionāli latviešu skaitam [?] bez tuvākiem noteikumiem". ${ }^{33}$

${ }^{28}$ Vēlāk dzejnieks bija viens no aktīvākajiem latviešu kā valsts valodas aizstāvjiem 1922. gadā Satversmes sapulces debatēs par Satversmes 115. pantu un arī 4. Saeimas diskusijā par 1932. gada speciālā valsts valodas likuma normām.

29 Tautas padomes 4. sesijas 8. sēdes 1919. gada 27. augustā stenogramma.

30 "Pārlabojumi un jautājumi, kuri ierosināti pa sēdes laiku un ceḷami uz balsošanu uz Tautas Padomes locekḷa - valsts valodas nepratēja - lūgumu, pārtulkojami krievu valodā. Tulkošanu prezidents var uzticēt sevišķam tulkam.” Sk. Latvijas Tautas padomes kārtības rullis 23.08.1919., 38. panta otrā dal̦a. No: Likumu un Valdības Rìkojumu Kräjums. 11, 1919.

31 Tautas padomes politiskā platforma: pieņemta Latvijas Tautas padomes sēdē 17.11.1918., 3. panta otrā dal̦a. Valdības Vēstnesis. 1, 14.12.1918.

32 Paegle, S. (1939). Kä Latvijas valsts tapa. Otrais izd. Rīga: Liepājas Burtnieks, 212.

33 Savās atmin̄ās Ādolfs Klīve norāda, ka Ulmanis, "atstājot minoritātēm deputātu sūtīšanu uz Tautas padomi pēc neierobežota pašu ieskata”, esot piẹ̦āvis būtisku “inkonsekvenci”. Klīve pārmet Ulmanim, ka "dažas latviešu konservatīvās partijas Tautas padomē neuzṇēma, bet vācieši un citas minoritātes konservatīvos polītiķus uz TP varēja sūtīt bez ierobežojuma”. No: Klīve, Ā. (1969). Brīvā Latvija: Latvijas tap̌̌ana: atmiņas, vērojumi un atzinumi. Bruklina: Grāmatu Draugs, 234, 242. 
"Valsts valoda Latvijas Republikā ir latviešu valoda" zinātnisko komentāru papildinājums

Ir jānorāda, ka Tautas padomē jauni locekḷi tika uzṇemti kooptācijas kārtībā, kas nozīmē, ka priekšparlaments jaunus locekḷus uzṇēma, tos apstiprinot ar balsu vairākumu. Šāda kārtība tika praktizēta no TP nodibināšanas sākuma un vēlāk, 1919. gada 23. augustā, tā tika nostiprināta arī TP kārtības rullì. ${ }^{34}$ TP darbības laikā (1918-1920) tās locekḷu skaits būtiski pieauga, kas ietekmēja attiecīgi arī minoritāšu pārstāvniecību. TP dibināja 40 delegāti 1918. gada 17. decembrī, un starp viṇiem nebija neviena mazākumtautību pārstāvja, bet pēc pāris nedẹlām, sanākot kopā uz pirmo sesiju, TP piedalījās 53 latviešu deputāti, pieci vācu un trīs ebreju tautības pārstāvji. ${ }^{35} \mathrm{TP}$ darbību noslēdzot, tajā bija 245(!), pēc citiem datiem - 297 dalïbnieki. Tas nozìmē, ka TP prezidijam vajadzēja rūpīgi izvērtēt katru jaunu partijas iesniegumu par uzṇemšanu TP. Nemot vērā to, ka priekšparlaments ne tikai teicami tika galā ar izsvērtu likumdošanu, bet arī spēja gādāt par normālu parlamenta pienākumu veikšanu (TP spēja nodrošināt labu darba organizāciju), ir pamats domāt, ka TP prezidijam izdevās salāgot sākotnēji pielemtās proporcijas un piedāvāto kandidātu kvalifikāciju. Pamatdarba valoda bija latviešu valoda, un lietvedība tika kārtota latviešu valodā, tādējādi var pieņemt, ka, mazākumtautību delegātus apstiprinot, notika arī Pauḷuka 1919. gada 27. augusta sēdē minētā vienošanās par latviešu valodu kā oficiālo valodu.

Tas ir gluži saprotami, ka Latvijas Republikā latviešu valoda ir oficiālā saziṇas valoda, taču intereses vērts ir fakts, ka līdztekus latviešu valodai kā parlamentā, tā arī pašvaldībās savu vietu pirmajā neatkarības laikā ienẹema krievu un vācu valoda. ${ }^{36}$ Šeit svarīgi ir piebilst, ka latviešu valodas tiesiskais stāvoklis nebija noteikts Satversmē. Līdz 1932. gadam krievu un vācu valodai bija priviligēeāass statuss iepretīm citām svešvalodām. Tautas padomē sākās, Satversmes sapulcē turpinājās, bet starpkaru Saeimās deputātu savstarpējā sazinnā nostiprinājās faktiska trīsvalodība. Lietvedība Saeimā tika kārtota tikai latviešu valodā, ${ }^{37}$ tomēr deputāti, pēc izvēles, sēdēs varēja runāt latviešu, krievu, vācu valodā, kā arī latgaliešu izloksnē. Latgaliešu runas jau stenografējot pārveidoja literārā latviešu valodā, bet krievu un vācu valodā teiktās runas (pareizāk, to atreferējumus)

${ }^{34}$ Pirmkārt, attiecīgā partija vēršas ar lūgumu Tautas padomes prezidijā (norādot konkrētus delegātus). Otrkārt, prezidijā tiek izskatīts šis lūgums. Treškārt, Tautas padomes kopsēdē ar balsu vairākumu tiek lemts par partijas virzīto delegātu mandātu atzǐ̌anu (kooptācija). Sk. Latvijas Republikas Tautas Padomes kārtības rullis: 23.08.1919., 1. un 2. pants. Likumu un Valdības Rīkojumu Krājums. 11, 1919.

35 Paegle, S. (1939). Kā Latvijas valsts tapa. Otrais izd. Rīga: Liepājas Burtnieks, 228.

${ }^{36}$ Balstoties uz Saeimas stenogrammu izpēti, var izdarīt visai pārliecinošu pien̦ēmumu, ka dal̦a minoritāšu deputātu nevis nemācēja, bet politisku iemeslu dēḷ nevēlējās runāt latviešu valodā, savukārt panākt tikai latviešu valodas lietošanu parlamentā un pašvaldībās nebija izteiktas politiskas gribas. Saeimas sastāvs, līdzīgi kā mūsdienās, bija visai sadrumstalots. Koalīcijas bija vājas un nevienam nebija spēka iegūt uz "sava kakla" organizētas piecu, sešu cilvēku lielas vācu minoritātes frakcijas deputātus un tikpat daudz krievu tautības pārstāvju...

37 "Katrs Saeimai priekšā ceḷams iesniegums rakstiski formulējams latviešu valodā un no iesniedzēja parakstāms”. Sk. Saeimas kārtības rullis: 26.03.1923., 45. pants. Valdības Vēstnesis. 65, 27.03.1923. https://tzpi.lu.lv/likumdeveja-kartibas-rullis/ 
"Valsts valoda Latvijas Republikā ir latviešu valoda" zinātnisko komentāru papildinājums

saskaṇā ar Saeimas kārtības rulli (1923. un 1929.) ${ }^{38}$ pašiem runātājiem bija jāiesniedz stenogrammu nodal̦ā. ${ }^{39}$ Izṇēmums (to var uzskatìt par tā laika konstitucionālu parašu) bija referentu pienākums runāt latviešu valodā valsts budžetu pieṇemot. ${ }^{40}$ Faktisko trīsvalodību saziñā krietni samazināja, taču pilnībā to neatcēla arī 1932. gada Valsts valodas noteikumi ar likuma spēku ${ }^{41}$ un pat ne 1935. gada Valsts valodas likums.

Latviešu valodas juridiskais statuss lïdz pat 1932. gadam bija nenoteikts par spïti vairākiem normatĩvajiem aktiem, kuros latviešu valoda tika saukta par valsts valodu. Pirmo reizi latviešu valoda par valsts valodu ir nosaukta 1918. gada 16. decembra Pagaidu nolikumā par Latvijas tiesām un tiesāšanās kārtību (10. pants) ${ }^{42}$ un vēlāk arī citos tiesību aktos, piemēram, 1919. gada 23. augusta Tautas padomes kārtības rullī (38. pants), 1919. gada 8. decembra likumā "Par Latvijas izglītības iestādēm" (8. pants), ${ }^{43}$ 1921. gada 22. novembra Ministru kabineta noteikumos "Par ierēdṇu pārbaudī̌anu valsts valodas

${ }^{38}$ Saeimas 1923. gada kārtības rullī un arī tā aizvietotājā - 1929. gada Saeimas kārtības rullī - tika noteikts, ka gadījumā, ja deputāts sēžu laikā runā vāciski vai krieviski, tad tautas priekšstāvim pašam ir jānodrošina runas tulkojuma iesniegšana Saeimas stenogrammu birojā. No paša deputāta, kas izvēlējās runāt šajās valodās, bija atkarīgs, vai sēdē sacītais parādījās stenogrammās. Sk.: Saeimas kārtības rullis: 26.03.1923., 146. pants. Valdības Vēstnesis. 65, 27.03.1923.; Saeimas kārtības rullis: 20.03.1929., 147. un 148. pants. Valdības Vēstnesis. 79, 10.04.1929. Tiesību zinàtṇu pētniecības institūts. https://tzpi.lu.lv/likumdeveja-kartibas-rullis/

Par šā regulējuma darbību viegli var pārliecināties, ielūkojoties stenogrammās. Tā piemēram, 1. Saeimas sēžu stenogrammās pie deputāta Markusa Nuroka (frakcijas "Agudas Izrael” loceklis) teiktā var lasīt stenogrāfistu piezīmi, ka runātājs ir uzstājies vācu valodā un tālāk zemsvītras atsaucē piebilsts, ka teksts ir runas atreferējums latviešu valodā. To pašu var redzēt, ieskatoties deputāta Maksa Lazersona (frakcija "Ceire Cion”) runas tekstā. Tur gan rakstīts, ka viṇš runā krievu valodā. Sk. Latvijas Republikas 1. Saeimas 1. sesijas 7. sēdes 1922. gada 13. decembrī stenogrammu. Tiesību zinātṇu pètniecības institūts. http://tzpi.lu.lv/pirmais-neatkaribas-laiks/saeimas-stenogrammas/

${ }^{39}$ Ja runu atreferējumi netika iesniegti, stenogrammā tie arī neparādās. Piemēram, stenogrammā pie Saeimas deputāta Leonīda Jeršova (Strādnieku un zemnieku frakcija) uzvārda nav runas teksta, bet lasāma piezīme, ka deputāts uzstājies krievu valodā un "runas atreferējums nav iesniegts". Sk. Latvijas Republikas 3. Saeimas 8. sesijas 1. sēdes 1931. gada 20. janvārī stenogrammu. Tiesību zinātṇu pētniecības institūts. http://tzpi.lu.lv/pirmais-neatkaribas-laiks/saeimas-stenogrammas/

40 Piemēram, 1929. gada 8. februāra sēdē Saeimas deputātam V. Piguḷevskim, kuram bija jāziṇo par 1928./29. gada budžeta nodokḷu atlaidi sakarā ar plūdiem, krusām un neražām. Stenogramma liecina, ka viṇš runu uzsāka krievu valodā, taču pēc starpsaucieniem zālē un sēdes vadītāja aizrādījuma pārgāja uz latviešu valodu, ko, spriežot pēc stenogrammas, referents pārvaldīja teicami. Sk. Latvijas Republikas 3. Saeimas 2. sesijas 6. sēdes 1929. gada 8. februāra stenogrammu. Tiesību zinātṇu pētniecības institūts. http://tzpi.lu.lv/pirmais-neatkaribas-laiks/saeimas-stenogrammas/

${ }^{41}$ Noteikumi par valsts valodu (izdoti Latvijas Republikas Satversmes 81. panta kārtībā): 18.02.1932. Valdìbas Vèstnesis. 39, 18.02.1932.

42 Par Latvijas tiesām un tiesāšanās kārtību: Tautas padomes pagaidu nolikums, 10. pants. Latvijas Pagaidu Valdības Likumu un Rīkojumu Krājums. 1, 15.07.1919.

${ }^{43}$ Likums par Latvijas izglītības iestādēm: 08.12.1919. Likumu un Valdības Rīkojumu Krājums. 13, 31.12.1919. 
"Valsts valoda Latvijas Republikā ir latviešu valoda" zinātnisko komentāru papildinājums

prašanā", ${ }^{44}$ 1923. gada 4. oktobra Satversmes 81. panta kārtībā izdotajos noteikumos ar likuma spēku "Noteikumi par Latgales apgabaltiesas vecākā notāra darbības atjaunošanu attiecībā uz aktu apstiprināšanu" ${ }^{45}$ un 1924. gada 17. novembra likumā "Par virsnieku un kara ierēdṇu pārbaudīšanu valsts valodas prašanā". ${ }^{46}$ Likumos ir manāma arī nekonsekvence jēdziena lietošanā, piemēram, 1923. gada 18. jūlija Likumā par sapulcēm ${ }^{47}$ tika runāts par sapulcēm, ko sarīko ārzemnieki, kā arī par "valodas brīvību", taču tajā nav jēdziena "valsts valoda". Lìdzīgi ir arī 1923. gada 23. aprịla likumā, kas apstiprināja Latvijas Universitātes Satversmi. Satversmes 3. punktā tika runāts par latviešu valodu, nevis par valsts valodu, ${ }^{48}$ kas, kā zināms, l̦āva pamatpriekšmetus mācìt gan vācu, gan krievu valodā. Spilgts piemērs ir vienā dienā - 1919. gada 8. decembrī - pieṇemtais likums "Par Latvijas izglīî̉bas iestādēm" un "Par mazākuma tautību skolu iekārtu Latvijā". ${ }^{49}$ Vienā likumā parādās jēdziens "valsts valoda", bet otrā no tā lietošanas likumdevējs ir izvairïjies. Tas skaidrojams ar to, ka tiesību normu hierarhijā nebija noteikts valsts valodas statuss un nebija arī konsekventas valsts valodas politikas. Situācija mainījās tikai pēc tam, kad 1932. gada 18. februārī tika pieņemti Valsts valodas noteikumi ar likuma spēku un beidzot tika noteikts latviešu valodas statuss. No šì brīža sāka mainīties attieksme pret valodu lietošanu ne tikai pašã valsts pārvaldē, bet arī ārpus tās.

Satversmes sapulcei caurskatot Satversmes otro daḷu, mazākumtautības debatēt par 115. pantu ${ }^{50}$ negāja. To var izskaidrot ar apstākli, ka šā panta otrais teikums ${ }^{51}$ ietvēra apñemšanos izstrādāt speciālu MVL, pie kura tieši tobrīd noritēja aktīvs darbs

${ }^{44}$ Noteikumi par ierēdṇu pārbaudīšanu valsts valodas prašanā: 22.11.1921. Valdības Vēstnesis. 269, 28.11.1921.

${ }^{45}$ Noteikumi par Latgales apgabaltiesas vecākā notara darbības atjaunošanu attiecībā uz aktu apstiprināšanu (izdoti Latvijas Republikas Satversmes 81. panta kārtībā): 04.10.1923. Valdības Vēstnesis. 222, 08.10.1923.

${ }^{46}$ Likums par virsnieku un kara ierēdṇu pārbaudīšanu valsts valodas prašanā: 17.11.1924. Valdības Vèstnesis. 262, 22.11.1924.

${ }^{47}$ Likums par sapulcēm: 18.07.1923. Valdìbas Vēstnesis. 152, 18.07.1923.

${ }^{48}$ Latvijas Universitātes Satversme: 27.04.1923., 3. punkts. Valdības Vēstnesis. 66, 28.03.1923.

${ }^{49}$ Likums par mazākuma tautību skolu iekārtu Latvijā: 08.12.1919. Likumu un Valdības Rīkojumu Kräjums. 13, 31.12.1919.

${ }^{50}$ Sākotnējā Satversmes 115. panta redakcija tika pien,emta Satversmes otrās apakškomisijas sēdē 1921. gada 29. aprīlī, piedaloties četriem apakškomisijas locekḷiem: Fricim Jansonam, Andrejam Kuršinskim, Paulam Kalniṇam un Jakovam Helmanim (kā mazākumtautību pārstāvim). Sēdē bez jebkādām diskusijām pieṇēma un ieprotokolēja jaunu Satversmes projekta normu: "Latviešu valoda ir valsts valoda. Mazākuma tiesību piederīgiem tiek garantēta viṇu valodas svabada lietošana kā runā, tā arī rakstos.” Sk. Satversmes 2. apakškomisijas 1921. gada 29. aprīḷa sēdes protokolu Nr. 60. Nav publicēts.

${ }^{51}$ Satversmes otrās daḷas projekta 115. panta redakcija bija šāda: "Latviešu valoda ir valsts valoda. Mazākuma tautību piederīgiem ir garantēta viṇu valodas brīva lietošana kā runā, tā arī rakstos. Kādas mazākuma tautību valodas un cik tālu pielaižamas valsts pašvaldības un tiesu iestādēs, noteic sevišks likums." 
"Valsts valoda Latvijas Republikā ir latviešu valoda" zinātnisko komentāru papildinājums

Satversmes izstrādes komisijā. ${ }^{52}$ No komentāriem sēdes laikā vairījās pat Pauls Šīmanis, kurš Satversmes komisijā nesekmīgi bija centies 115. panta otrajā teikumā mainìt, pēc viṇa domām, abstrakti interpretējamu juridisku jēdzienu "mazākuma tautības" pret konkrētu tautību uzskaitījumu (ebreju, vācu un krievu). ${ }^{53}$ Arī šie MVL projekti līdz mūsu dienām nav saglabājušies, taču galvenās iezīmes ir redzamas Satversmes izstrādes komisijas protokolos. ${ }^{54}$ Regulējums tajos pārspēj iepriekš aprakstīto TP projektu. Vairs netiek runāts par algoritmiem, kas balstïtos uz divdesmit vai piecdesmit procentiem, bet uz piecdesmit vai pat desmit procentiem (kā kurā likumprojektā) mazākumtautību dzìvojošo attiecīgajā pašvaldībā. Piemēra pēc var ieskatīties Lielkrievu likumprojekta 45. panta redakcijā, kas pilnā apjomā tiek citēta komisijas protokolā: "Visās tanīs Latvijas pašvaldības vienībās, kurās lielkrievi sastāda ne mazāk kā $10 \%$ no vispārējā iedzīvotāju skaita, iedzīvotājiem ir tiesība griezties pie visiem - tiesu, valsts un pašvaldības iestādēm - kā mutiski, tā arī rakstiski lielkrievu valodā." Likumprojekta nākamajā, t. i., 46. pantā, noteikts: "Visi vietējie valdības un pašvaldības iestāžu rīkojumi publicējami vispārējai zināšanai arī krievu valodā." Bet savukārt 49. pantā rakstīts, ka "tiesu iestādēs prāvniekiem aț̣auts rakstos un vārdos lietot lielkrievu valodu". Grūti pateikt, kādi būtu bijuši algoritmi, ja komisijas MVL projekts būtu nonācis līdz Satversmes sapulces pirmajam lasījumam, taču tam nebija lemts notikt.

Kad kḷuva skaidrs, ka iecere par Satversmes otro dạı ir pilnīgi izgāzusies un latviešu valoda netiks konstitucionāli noteikta, un tādējādi nebūs arī pie 115. panta piebildes par mazākumtautību valodu speciālajiem likumiem, tika pielikts punkts MVL projektam. Satversmes komisijas 1922. gada 14. jūlija sēdē, ${ }^{55}$ noslēdzot komisijas darbu, tās priekšsēdētājs Marğers Skujenieks, atvadoties no Satversmes komisijas locekḷiem, sacija: "Nav ko domāt, ka šis likums [MVL] komisijā šinī [Satversmes sapulces] sesijā vēl varētu tikt pien,emts, kamdēḷ tas no dienas kārtības tiek noṇemts." Protokolā ir fiksēts Skujenieka

52 Sākumā bija ideja gatavot vairākus MVL - krieviem savu, vāciešiem savu un ebrejiem savu. Šāda pieeja tika atbalstīta Satversmes komisijā, kurā MVL skatīja trīs lasījumos un gatavoja iesniegšanai Satversmes sapulces prezidijam tālākai virzībai sēdē. No Satversmes komisijas protokolos piefiksētajiem fragmentiem ir saprotams, ka Šìmanis bija galvenais šo likumu virzìtājs un turpināja savas jau TP iesāktās iestrādes šai virzienā. Komisijas protokolos lasāms, ka komisija pēc Šìmaṇa ieteikuma nolēma dažādu mazākumtautību likumus apvienot vienā ("vācu un lielkrievu valodu likumus" savienot vienā likumprojektā un izdarìt to trešajā lasījumā), par ko komisija iebildumus necēla. Sk. Satversmes komisijas 1921. gada 3. novembra sēdes protokolu Nr. 58; Satversmes komisijas 1922. gada 8. jūlija sēdes protokolu Nr. 70 un Satversmes komisijas 1922. gada 14. jūlija sēdes protokolu Nr. 77. Tiesību zinātṇu pētniecības institūts. https://tzpi.lu.lv/satversmes-sapulces-komisijas-sezu-protokoli/

53 Satversmes komisijas 1921. gada 3. novembra sēdes protokols Nr. 58. Tiesību zinātṇu pētniecības institūts. https://tzpi.lu.lv/satversmes-sapulces-komisijas-sezu-protokoli/

${ }^{54}$ Satversmes komisijas 1922. gada 8. jūlija sēdes protokols Nr. 70. Tiesību zinātṇu pētniecības institüts. https://tzpi.lu.lv/satversmes-sapulces-komisijas-sezu-protokoli/

${ }^{55}$ Satversmes komisijas 1922. gada 14. jūlija sēdes protokols Nr. 77. Tiesību zinātṇu pētniecības institüts. https://tzpi.lu.lv/satversmes-sapulces-komisijas-sezu-protokoli/ 
"Valsts valoda Latvijas Republikā ir latviešu valoda" zinātnisko komentāru papildinājums

paskaidrojums. Darbs netiek turpināts, jo apakškomisija nespēj sanākt uz sēdi, lai nolemtu par MVL trešo lasijumu. Protokolā ir ierakstìts, ka "komisijas priekšsēdētājs vēl konstatē, ka Satversmes komisija ir veikusi savu darbu un tamdēḷ tās sēdes ir pārtraucamas." 56

İstais iemesls, visticamāk, nav saistāms ar komisijas darba organizāciju, drīzāk jau ar to apstākli, ka latviešu valoda tā arī netika nostiprināta valsts pamatlikumā par valsts valodu, un līdz ar to tālāk netika virzīti arī mazākumtautību atseviškie valodu regulējumi. Jautājumu par latviešu valodu kā valsts valodu turpmākos desmit gadus Latvijas likumdevējs vairs nekustināja.

Latgalieši Satversmes sapulces 1922. gada 7. februāra sēdē iesaistỉjās asās debatēs par 115. pantu. Satversmes sapulces loceklis latgalietis Francis Kemps iesniedza priekšlikumu 115. panta pirmo teikumu "latviešu valoda ir valsts valoda" papildināt ar vārdiem "pie kam Latgales apgabalā par oficiālo valodu tiek atzìta latgaliešu izloksne". Šis priekšlikums tika noraidìts, tāpat kā visi citi latgaliešu priekšlikumi. ${ }^{57}$ Latgalē ievēlētie Satversmes sapulces locekḷi nepārprotami apvainojās un neskopojās izteikumos, debatēs paužot lielu satraukumu par asimilācijas politiku, ko pārējā Latvija realizē pret latgaliešiem. Franča Kempa ieskatā "latgaliskā izloksne" ir skaista un bagāta ${ }^{58}$ un smiešanās par to esot [pārējo latviešu] šovinisma izpausme. Tas nav "patriotisms" un nav arī "nopietna valsts būvēšana", bet tas ir "šovinisms pašas tautas iekšā", no Saeimas tribīnes sacīja Kemps. ${ }^{59}$ Viňš skumji secināja, ka izskatoties, ka pēc Satversmes pieņemšanas šādā redakcijā latgalieši atradīšoties daudz sliktākā situācijā nekā nacionālās minoritātes. Pārmetumi tika adresēti ne tikai ierēdṇiem, kas lemj par Latgales lietām, bet arī kolēgiem, Satversmes sapulces locekḷiem:

"Mūsu izloksne nav tik saprotama un nav tik mịḷa, kā mēs domājam, jo bieži vien mēs novērojam, ka, latgaliešiem nākot runāt, sapulce pa lielākai dal̦ai atstāj zāli. [..] no visām pusēm dzirdam un jūtam, ka to [latgaliešu izloksni] izsmej, izḳēmo, izjoko, pat noliedz." ${ }^{60}$ [..]

${ }^{56}$ Satversmes komisijas 1922. gada 14. jūlija sēdes protokols Nr. 77. Tiesību zinàtṇu pētniecības institūts. https://tzpi.lu.lv/satversmes-sapulces-komisijas-sezu-protokoli/

${ }^{57}$ Latgaliešu sarūgtinājums, skatot vienu no pēdējiem Satversmes likumprojekta pantiem, bija liels, un tas krājās jau ilgi. Sākumā, 1921. gada 5. oktobrī Satversmes sapulces kopsēdē otrajā lasījumā caurskatot Satversmes pirmo daḷu, tika noraidìts latgaliešu priekšlikums Satversmes 4. pantu izteikt šādi: "Latgale bauda apgabala pašvaldības tiesības, kuras nosakāmas ar atsevišku likumu." Toreiz latgaliešiem Marğers Skujenieks bija paskaidrojis, ka šāds jautājums var tikt aplūkots otro Satversmes dalı skatot. 1922. gada 4. aprīlī Satversmes sapulces kopsēdē trešajā lasījumā tika noraidīts otrais latgaliešu mēǵinājums papildināt ar līdzīgu satura redakciju Satversmes 99. pantu: "Latgale bauda plašas apgabala pašvaldības tiesības, kuras robežas nosaka atseviškss likums".

58 Satversmes sapulces 4. sesijas 8. sēdes 1921. gada 5. oktobrī stenogramma. No: Latvijas Satversmes sapulces stenogrammu izvilkums (1920-1922). Latvijas Republikas Satversmes projekta apspriešana un apstiprināšana. Rīga: Tiesu namu agentūra, 2006.

59 Turpat.

${ }^{60}$ Satversmes sapulces 4. sesijas 1921. gada 4. un 5. oktobra sēdes stenogramma. No: Latvijas Satversmes sapulces stenogrammu izvilkums (1920-1922). Latvijas Republikas Satversmes projekta apspriešana un apstiprināšana. Rīga: Tiesu namu aǵentūra, 2006. 
"Valsts valoda Latvijas Republikā ir latviešu valoda" zinātnisko komentāru papildinājums

"Dažās citās lietās, kā skolu un pašvaldību lietās, mēs [latgalieši] esam nostādīti zemāk nekā minoritātes un mums jau tagad vajadzīgs prasīt minoritāšu tiesības. Šai jautājumā mēs negribam arīdzan būt zemāki par minoritātēm." ${ }^{11}$

Protams, latgaliešiem blakus to latviskajai nacionāli kulturālai identitātei, kas ir kopēja visai latviešu nācijai, pastāv arī to specifiskā kultūrvēsturiskā identitāte. ${ }^{62}$ Bezspēcīgajām dusmām par viṇu visu likumdošanas iniciatīvu bloḳēšanu vajadzēja kaut kā izlauzties uz āru, un trešajā lasījumā vinịi atturējās balsojumā par Satversmes otro dalı. Saskaitot visas balsis, izrādījās, ka pietrūkst vien sešu balsu. ${ }^{63}$ Tas nozīmēja, ka pat ar pusi no organizēto latgaliešu balsīm ${ }^{64}$ būtu pilnīgi pieticis, lai Satversmes otrā dą̣a kḷūtu par Satversmes neatṇemamu daḷu. Atšḳirībā no Satversmes sapulces vairākuma, kas balsojumā atturējās vai balsoja pret likumprojektu, latgalieši izvēlējās nākt klajā ar paziṇojumu (motivāciju). Satversmes sapulcei pēc balsojuma bija jāuzklausa latgaliešu paziṇojums, ka vinii "atturējās tāpēc, ka, minēto Satversmes dalı caurskatot, tika noraidìts priekšlikums par Latgales apgabala pašvaldỉbu, kā arī nepien̦emti citi uz Latgali attiecošies pārlabojumi un papildinājumi". ${ }^{65}$ Šai paziṇojumā nešaubīgi jaušams savs dramaturğijas elements, jo, kā jau minēts, puses organizēto latgaliešu balsu būtu pilnīgi pieticis, lai šim Latvijas konstitucionālismam svarīgajam balsojumam būtu pozitīvs iznākums. Tā latgalieši pielika punktu divus gadus ilgušajai Satversmes otrās dalıas rakstǐšanai, lìdz ar to par Satversmes pieñemšanas datumu kḷuva 1922. gada 15. februāris. ${ }^{66}$

Latgaliešu centieniem ietvert Satversmes normās atsauces uz Latgales autonomiju un tiesībām uz izloksni nebija lemts piepildīties, līdz Zigfrīda Annas Meierovica vadìtais Ministru kabinets to valdības noteikumu līmenī atrisināja Satversmes izstrādes laikā. 1921. gadā valodas jomā tika pieṇemti vairāki noteikumi, kas attiecās arī uz Latgali vai tikai uz Latgales regiionu. Lai arī vairs nav iespējams pārliecināties par visu šo valdības

${ }^{61}$ Satversmes sapulces 4. sesijas 7. sēdes 1921. gada 4. oktobrī stenogramma. No: Latvijas Satversmes sapulces stenogrammu izvilkums (1920-1922). Latvijas Republikas Satversmes projekta apspriešana un apstiprināšana. Rīga: Tiesu namu agentūra, 2006.

${ }^{62}$ Levits, E. (2019). Valstsgriba. Idejas un domas Latvijai 1985-2018. Rīga: Latvijas Vēstnesis, 556-557.

${ }^{63}$ Balsojumā piedalījās 130 sapulces locekḷi, no tiem tikai 62 balsoja par Satversmes pieņemšanu. Lai gan pret bija tikai seši un atturējās 62, faktiski pret bija 68 balsis, jo atturējušos deputātu balsis tika pieskaitītas pret balsojušo skaitam. Saskaṇā ar Latvijas konstitucionālo tradīciju atturēties būtībā nozīmēja balsot pret, tikai izteikt to "maigākā formā". Šeit ir nepieciešams paskaidrot balsojuma "atturēties" nozīmi parlamentārismā. Atturēties balsojumā nenozīmē būt pasīvam. Latgaliešu deputāti, tāpat visi pārējie sapulces locekḷi, kas atturējās liktenīgajā balsojumā, nebija pret Satversmes otro dalı principā, jo šādā gadījumā viṇi izvēlētos balsotu pret. Šādi balsojot, politiḳi izrādīja attieksmi pret lēmumprojektu vai konkrētā gadījumā - likumprojektu. Ja balsojumā politiḳi atturas, tad, visbiežāk, viṇi vēlas parādīt, ka nav gatavi atbalstīt priekšlikumu, taču, ja priekšlikums būtu kvalitatīvākizstrādāts, deputāti to atbalstītu.

${ }^{64}$ Satversmes sapulces balsojumu analĩze liecina, ka latgaliešiem bija 17 vai 18 balsis, kas nozīmē, ka pat mazāk par pusi latgaliešu balsu būtu pilnīgi pieticis Satversmes otrās daḷas pien,emšanai.

${ }^{65}$ Latvijas Satversmes sapulces 5. sesijas 34. sēdes 1922. gada 5. aprīlī stenogramma.

${ }^{66}$ Balodis, R. (2021). Kā cīṇa par latgaliešu valodu ietekmēja latviešu valodas statusu. Jurista Vārds. $38,21.09 .2021$. 
"Valsts valoda Latvijas Republikā ir latviešu valoda" zinātnisko komentāru papildinājums

noteikumu efektivitāti, tomēr valdību var uzteikt par stingro politisko gribu sakārtot latgaliešu jautājumu valdības noteikumu līmenī. Tāpat bez papildu informācijas ir grūti spriest, kādēl ar šiem noteikumiem nepietika un latgaliešiem škita, ka vinu jautājums tomēr nav tiesiski noregulēts, un viņi atturējās izšḳirošajā balsojumā par Satversmes otro daḷu.

1921. gada 22. novembrī tika pieñemti Ministru kabineta "Noteikumi par ierēdṇu pārbaudī̌̌nu valsts valodas prašanā", ${ }^{67}$ kuros bija paredzēts, ka tiem, "kuri pietiekoši nepārvalda valsts valodu, bet vēlas palikt valsts iestādes dienestā", ir iespēja gada laikā iemācìties tekoši runāt latviski. Pēc noteiktā terminna viṇu prasmes novērtēs ìpaša komisija. Latgalei termiņš tika pagarināts, nosakot pārbaudes laiku pēc diviem gadiem.

1921. gada 11. jūnijā tika pieņemti Ministru kabineta "Noteikumi par latgaliešu izloksnes lietošanu", ${ }^{68}$ kuros bija noteikts, ka "visām valsts iestādēm un amata personām" turpmāk jāpieṇem iesniegumi, kas rakstīti latgaliešu izloksnē. Tādējādi tika pieḷauta atkāpe no latviešu literārās valodas lietošanas Latgales reǵionā. Noteikumi gan bija visai lakoniski, sastāvoši tikai no diviem punktiem, tomēr to pozitīvā ietekme bija ievērojama. Tajos bija paredzēts, ka turpmāk amatpersonām, valsts un pašvaldības iestādēm ir "tiesība lietot latgaliešu izloksni darbvedībā un sarakstoties, kā arī sludinājumos, uz izkārtnēm u. t. t.”.

1921. gada 30. jūnijā tika pien,emti Ministru kabineta "Noteikumi par Latgales lietu pārzināšanu”, ${ }^{69}$ kuri reglamentēja, ka Iekšlietu ministrijas (turpmāk - IeM) Latgales lietu departamenta vietā, kas bija izsaucis latgaliešu neapmierinātību, tiek izveidota augstākas pakāpes ierēdña - IeM ministra biedra Latgales lietās - amata vienība. Šai amatpersonai bija paredzēta plaša kompetence tieši Latgales lietās, kas ietvēra tiesības pieprasìt no jebkuras ministrijas un iestādes ziṇas par tās resora darbību Latgalē. Tāpat šajos noteikumos bija paredzēta IeM ministra biedra Latgales lietās kompetence sniegt atsauksmes par ierēdṇu iecelšanu Latgales regionā.

1921. gada 26. jūlijā Ministru kabinets izdeva arī "Noteikumus par ierēdṇu iecelšanu Latgalē", ${ }^{70}$ kuros faktiski tika papildināti jau 30. jūnijā izdotie noteikumi. Saskaṇā ar šiem noteikumiem valsts "centrālām iestādēm" bija pienākums saskaṇot ar IeM biedru Latgales lietās visus ierēdṇus, kas tiek iecelti "Latgales vajadzībām". Noteikumos bija paredzēts, ka, ieceḷot ierēdṇus Latgalē, "priekšrocīb[a] jādod tiem kandidātiem, pie citām līdzīgām īpašībām, kas prot latgaliešu izloksni un pazīst vietējos apstākḷus".

Pēc tam, kad 1922. gada 5. aprīlì trešo lasỉjumu nepārvarēja Satversmes otrā daḷa, Satversmes sapulcei cits neatlikta, kā 1922. gada 15. februārī apstiprināto Satversmes pirmo daḷu 1922. gada 30. jūnijā izsludināt kā Satversmes pamattekstu. Mazākumtautību juristi Satversmi nodēvēja par Rumpf-Verffassung ${ }^{71}$ (ir rumpis, taču nav galvas), ko var saprast

\footnotetext{
${ }^{67}$ Noteikumi par ierēdṇu pārbaudīšanu valsts valodas prašanā: 22.11.1921. Valdības Vēstnesis. 269, 28.11.1921.

${ }^{68}$ Noteikumi par latgaliešu izloksnes lietošanu: 11.08.1921. Valdības Vēstnesis. 183, 17.08.1921.

${ }^{69}$ Noteikumi par Latgales lietu pārzināšanu: 30.06.1921. Valdības Vēstnesis. 177, 10.08.1921.

${ }^{70}$ Noteikumi par ierēdṇu iecelšanu Latgalē: 26.07.1921. Valdības Vēstnesis. 174, 06.08.1921.

${ }^{71}$ Lazdinšs, J. (2014). Rechtspolitische Besonderheiten bei der Entstehung des lettischen Staates und seiner Verfassung. Law. 7, 17.
} 
"Valsts valoda Latvijas Republikā ir latviešu valoda" zinātnisko komentāru papildinājums

divējādi: no vienas puses, kā konstitūciju, kurai nav galvenās cilvēku pamattiesību sadaḷas; no otras puses, kā latviešu Latvijas Republikas titulnācijas nespēju noteikt savai valodai augstāko konstitucionālo rangu. Lai gan netika pārtraukta bruṇoto spēku un civildienesta pamatsastāva normatīvā regulējuma pilnveidošana attiecībā uz valsts valodas prasmju pārbaudīšanu, ${ }^{72}$ tomēr desmit gadus valsts valodas jautājums pirmajās trijās Saeimās cilāts netika. Kad 4. Saeima 1931. gada decembrī apstiprināja Margéeru Skujenieku par Ministru prezidentu, valsts valodas jautājums tika pacelts no jauna. Skujeniekam šĩ bija otrā reize, kad viņ̧̌ tika apstiprināts par premjerministru. Pieredzējušais politikis savas politiskās karjeras sākumposmā bija sociāldemokrāts mazinieks, bet laika gaitā kḷuva par visai labēju politiḳi, kas realizēja nacionālu politiku. Satversmes sapulcē viņ̌̌ vadīja Satversmes izstrādes komisiju un 1931. gadā, uzreiz pēc kḷušanas par Ministru prezidentu, aktivizēja latviešu valodas valstiskošanas jautājumu. Tika izmantota bēdīgi slavenā ${ }^{73}$ Satversmes 81. panta iespēja izdot valdības noteikumus ar likuma spēku ("laikā starp Saeimas sesijām Ministru kabinetam ir tiesïba, ja neatliekama vajadzỉba to prasa, izdot noteikumus, kuriem ir likuma spēks"). Ministru kabinets "Noteikumus par valsts valodu" pienēema 1932. gada 18. februārī Satversmes 81. panta kārtībā. ${ }^{74}$ Saeimā debates par šo regulējumu notika 1932. gada 23. februāra sēdē, ${ }^{75}$ kurā mazākumtautību politiḳi vienoti iestājās pret jauno regulējumu, uzskatot to par savu tiesību ierobežošanu. Pret latviešu valodu kā valsts valodu iestājās arī sociāldemokrātu frakcija, kuras deputāts Fricis Menderis paziṇoja, ka sociāldemokrātiem tuvākas ir minoritāšu tiesības, nevis latviešu pilsonība ar "savām interesēm". Pauls Šīmanis tiesību aktu dēvēja par "tautību naidu izsaucošu", kas pēc būtības esot "valsts paziņojums minoritātēm, ka tās ir svešas valstij [..]", un, pēc viṇa domām, tas esot vien "veikls valdības gājiens", kas domāts, lai novērstu uzmanību no valdības muitas un nodokḷ u politikas. ${ }^{76}$ Sēdē nesnauda arī komunisti, kas visiem pa vidu neveiksmīgi centās provocēt latgaliešu izloksnes

${ }^{72}$ Likums par virsnieku un kara ierēdṇu pārbaudīšanu valsts valodas prašanā: 17.11.1924. Valdības Vèstnesis. 262. 22.11.1924.

${ }^{73}$ Smiltēna, A. (2016). Deleǵétas likumdošanas pirmsākumi Eiropā un Latvijāa: promocijas darbs. Rīga: Latvijas Universitāte, 24.; Satversmes tiesas 2005. gada 16. decembra spriedums lietā Nr. 2005-120103, Secinājumu dal̦a, 17. punkts.

${ }^{74}$ Noteikumi par valsts valodu: izdoti Latvijas Republikas Satversmes 81. panta kārtībā: 18.02.1932. Valdïbas Vèstnesis. 39, 18.02.1932.

${ }^{75}$ Latvijas Republikas 4. Saeimas 2. sesijas 2. sēdes 1932. gada 23. februārī stenogramma. Tiesību zinātñu pētniecības institūts. https://tzpi.lu.lv/pirmais-neatkaribas-laiks/saeimas-stenogrammas/

${ }^{76}$ Pauls Šìmanis, laikraksta "Rìgas Apskats" (Rigische Rundschau) vadītājs, kā publicists vēl sarunāja daudz ko un runu noslēdza ar dramatisku nelatviešu situācijas aprakstu: "Pretēji pārējām Baltijas valstīm Latvija ir ieguvusi sev ārzemēs pat zināmu slavu tādā ziṇā, ka ar katru, kas neprot valsts valodu, šeit apietas slikti, un tam rodas visādas grūtības. [..] Svešā valodā rakstīti materiāli visupirms jāpārtulko, iekams ierēdnis tos drīkst lietot, vienalga, vai viņš svešo valodu prot vai nē. Kas grib lietot ielas dzelzcel̦u [tramvaju], bet neprot latviski, lai n̦em sev līdzi ceḷojumā tulku." Jāpiezīmē, ka šo runu, tāpat kā visas citas, Šīmanis Saeimā norunāja vāciski. Sk. Latvijas Republikas 4. Saeimas 2. sesijas 2. sēdes 1932. gada 23. februārī stenogrammu. Tiesību zinātṇu pētniecības institūts. https://zpi.lu.lv/pirmais-neatkaribas-laiks/saeimas-stenogrammas/ 
"Valsts valoda Latvijas Republikā ir latviešu valoda" zinātnisko komentāru papildinājums

tematiku. Valodas noteikumus metās aizstāvēt pats Ministru prezidents Skujenieks, kurš no Saeimas tribīnes runāja par jaunu paaudzi, kas izaugusi brīvajā Latvijā un nemaz neprot citādi runāt kā tikai latviski. Šì paaudze gaidot jaunā regulējuma pieṇemšanu. Valsts jaunā latviešu paaudze grib atvērt cel̦u dzìvē, tādēl Skujenieks lūdza Saeimu atbalstìt noteikumus. Ministru prezidents minēja konkrētus gadījumus, ka latviešu jaunieši tikuši diskriminēti un nepieṇemti darbā tāpēc vien, ka tie neprotot krievu vai vācu valodu. Sēdē savu viedokli pauda arī Kārlis Skalbe sakot, ka šis

\begin{abstract}
"[..] likums izdodams aiz vienkāršas cieṇas pret mūsu valsti. Ja mēs cienām savu valsti, tad mēs cienām valsts valodu. Kur ir valsts, tur ir valsts valoda. Šì valsts valoda Latvijā nevar būt cita kā latviešu valoda, jo latviešu tauta šeit ir lielā vairākumā. [..] Latvija var būt tikai latviska! [..] Katrai valstij ir zināms mugurkauls, un šis mugurkauls ir vairākuma tauta, viñas valoda un kultūra."77
\end{abstract}

Noteikumiem ir likuma spēks, kas nozīmē to, ka tiesību sistēmā starp šiem noteikumiem un likumu nav atšḳirības juridiskā spēka ziṇā. Pirmo reizi Latvijas valsts pastāvēšanas vēsturē tika noteikts, ka valsts valoda ir latviešu valoda. Noteikumi reglamentēja obligātu valsts valodas lietošanu Latvijas bruṇotajos spēkos, valsts un pašvaldības iestādēs un uzṇēmumos, kā arī "visos privātos iestādījumos ar publiski tiesisku raksturu". Regulējums privātajā sektorā pieḷāva mazākumtautībām kārtot iekšējo lietvedību citā valodā, savukārt saziṇu ar valsts institūcijām (atskaites u. tml.) paredzēja tikai valsts valodā. Noteikumi ar likuma spēku pieḷāva krievu un vācu valodas lietošanu pašvaldībās, nosakot 2. pantā algoritmu, kas pieḷauj krievu un vācu valodas lietošanu pašvaldībās, vajadzēja gan ievērot nosacỉjumu, ka tajās vismaz puse iedzīvotāju runā kādā no minētajām valodām. Šis piemērs labi ilustrē vācu un krievu valodas patiesās lietošanas apjomu tā laika Latvijas atsevišşās pašvaldībās. Regulējums arī liecina par visai liberālu valodas politiku attiecībā uz minētajām divām svešvalodām pirmā neatkarības perioda laikā. Bija noteikts, ka gadījumā, ja pašvaldības sēde norit svešvalodā un kādam no sēdes dalībniekiem šì svešvaloda nav saprotama, tad attiecīgai pašvaldībai ir jānodrošina tās tulkojums valsts valodā. Pēdējais nozīmē, ka likumdevējs bija identificējis šādus gadījumus, kurus var atrisināt tikai ar likumā paredzētu obligātu nosacījumu.

Lìdz ar Kārḷa Ulmaņa apvērsumu aktualizējās arī valsts valodas regulējums. Vien mēnesi pēc apvērsuma valdība pien̦ēma grozijumus 1932. gada 18. februāra noteikumos ar likuma spēku. Šajos 1934. gada 14. jūnija grozijumos ${ }^{78}$ tika noteikti bargi sodi par valsts valodas noteikumu pārkāpumiem. Turpmāk par tiem Iekšlietu ministrija varēja piemērot naudas sodu līdz pat tūkstoš latiem un personu arestu uz laiku līdz pat sešiem mēnešiem, ${ }^{79}$

${ }^{77}$ Latvijas Republikas 4. Saeimas 2. sesijas 2. sēdes 1932. gada 23. februārī stenogramma. Tiesību zinātñu pētniecības institūts. https://tzpi.lu.lv/pirmais-neatkaribas-laiks/saeimas-stenogrammas/

78 Pārgrozījumi un papildinājumi noteikumos par valsts valodu. Valdības Vēstnesis. 132, 16.06.1934.

${ }^{79}$ Lai saprastu tā laika lata vērtību, ir jāpiebilst, ka kvalificēts strādnieks vai jaunsaimnieks ar 100 latu ienākumiem mēnesī, kaut l̦oti pieticīgi, varēja nodrošināt pamata iztiku sievai un vienam vai diviem bērniem. 
vai pat piemērot abus sodus reizē. Par likuma darbību personīgi kḷuva atbildīgs iekšlietu ministrs. N̦emot vērā, ka valstī tika izsludināts kara stāvoklis, šie likuma grozījumi ievērojami sekmēja valsts valodas lietošanu. Savukārt 1935. gada 5. janvāra Valsts valodas likums ${ }^{80}$ juridiskā zin̄ā bija tehniska 1932. gada 18. februāra Satversmes 81. panta kārtībā pieņemto Ministru kabineta noteikumu un 1934. gada 14. jūnija Ulmaṇa valdỉbas grozijumu konsolidēta vesija, kas savā ziñā bija arī valdības propagandas solis. Likums, ko Ulmaṇa autoritārā valdība izdeva nedaudz vairāk nekā pusgadu pēc varas pārṇemšanas, bija jaunā režìma "simboliskais likums", kas raksturo rūpes par latviešu nāciju. Likums lieliski der šai "latviskās politikas" simbolizēšanas lomai, lai gan daži jauni nosacijjumi likumā ir līdz tam nebijuši. Piemēram, likuma 6. pantā paredzēts, ka rakstiskiem līgumiem, dāvinājuma aktiem, veksel̦iem, parādu un citiem saistību rakstiem, ja tos Latvijā pēc 1935. gada l. februāra slēdz Latvijas pilsoṇi, ir saistības un pierādỉjuma spēks vienīgi tad, ja tie rakstīti valsts valodā. Atbildīgu par likuma efektīvu darbību, tai skaitā sodiem, režīms noteica iekšlietu ministru. Kara stāvokḷa apstākḷos, nešaubīgi, tam bija stindzinošs efekts. Visticamāk, sava loma bija arī Marğeram Skujeniekam, kurš tobrīd bija viens no režīma vadon̦iem, - Ministru prezidenta biedrs. 1935. gada 5. janvāra Valsts valodas likums ir izcils Ulmaṇa sabiedrisko attiecību speciālistu un juristu sadarbības kopdarbs, kas parlamentārā laikā paveiktu darbu spēja padarīt par autoritārās varas panākumu. ${ }^{81}$

\section{Papildinājums Satversmes 4. panta komentārā minētajam par mūsdienu periodu}

Satversmes 4. panta komentāra sadaḷā "Valsts valodas statusa atjaunošana un latviešu valodas statusa nostiprināšana" ir norādīts:

"Latviešu valoda sāka atgūt savu statusu pagājušā gadsimta 80. gadu beigās. 1988. gada 6. oktobrī tika pieṇemts LPSR Augstākās padomes Lēmums par latviešu valodas statusu, bet 1989. gada 5. maijā LPSR Konstitūcija tika papildināta ar 73. ${ }^{1}$ pantu, kurā paredzēts, ka "Latvijas Padomju Sociālistiskajā Republikā valsts valoda ir latviešu valoda". [..] 1992. gada 31. martā tika pieṇemts Latvijas Republikas likums "Par grozijumiem un papildinājumiem LPSR Valodu likumā”. Šajos grozījumos un papildinājumos atspoguḷojās pārmaiṇas Latvijas valstiskajā statusā un tika nostiprināta valodu juridiskā hierarhija. [..] Valodu likumā tika noteikta latviešu valodas un citu valodu lietošana valsts, tautas saimniecības un sabiedriskās darbības sfērās, pilsoṇu valodas izvēles tiesības un valodu aizsardzības pasākumi. Atsevišḳas likuma normas stājās spēkā tikai trīs gadu laikā pēc likuma stāšanās spēkā. Pakāpeniskums latviešu valodas funkciju atjaunošanā bija nepieciešams, lai radītu materiālo bāzi latviešu valodas mācīšanai

${ }^{80}$ Likums par valsts valodu: LR likums: 05.01.1935. Valdības Vēstnesis. 7, 09.01.1935.

${ }^{81}$ Balodis, R. (2021). Par nepieciešamību valsts valodai atrast politisku aizbildni. Jurista Vãrds. 42, 19.10.2021. 
"Valsts valoda Latvijas Republikā ir latviešu valoda" zinātnisko komentāru papildinājums

un lietošanai valsts varas un pārvaldes institūcijās, kā arī [lai] panāktu psiholog̣isko lūzumu sabiedrībā." $\$ 2$

"Valsts valodas likums tika pienemts 1999. gada 9. decembrī, un tas ir secīgs posms Latvijas valodas politikā un galvenais instruments latviešu valodas statusa nodrošināšanā. Likumu papildina vairāki Ministru kabineta noteikumi, kas precizē atsevišķu pantu normas." 83

Minētajā Satversmes komentāra dạ̦ā pareizi ir iezīmēts Augstākās padomes 1988. gada 6. oktobra Lēmums par valsts valodu, ${ }^{84}$ un, lai gan netiek aplūkota 1989. gada 5. maija LPSR Valodu likuma pieñemšana, ir pieminēts 1992. gada 31. marta Latvijas Republikas likums "Par grozījumiem un papildinājumiem LPSR Valodu likumā". Tam ir liela nozìme, un faktiski abi šie normatīvie akti jāuztver kā jauns likums gan pēc savas formas, gan satura. Tieši šis likums sekmīgi darbojās pirmajos gados pēc neatkarības atgūšanas, pilnībā nodrošinot visus tiesiskos nosacijumus, kas izriet no latviešu valodas kā valsts valodas.

Vai lietderīgi un politiski tālredzīgi bija censties šo likumu nomainīt ar jaunu likumu tieši tajā laikā, kad, Latvijai uzsākot sarunas par iestāšanos Eiropas Savienībā, nācās savu tiesību sistēmu harmonizēt, pakḷaujot to dažnedažādu ekspertu analīzei? Tas ir jautājums, kurš liek aizdomāties par Latvijas kā nacionālas valsts spēju pieskaṇot taktisku rīcību, nosakot stratēgiskus mērķus. 1999. gada 9. decembra Valsts valodas likums ir labs atgādinājums konstitucionālās politikas jomā par to, ka bieži vien labāk ir iztikt ar senāku tiesību aktu, kas lieliski pilda savas funkcijas, nevis censties visiem spēkiem to nomainìt ar jaunāku.

Pagājušā gadsimta 80. gadu beigās Padomju Savienība sāka neatvairāmi tuvoties savam sabrukumam. Latvijā, tāpat kā pārējās divās Baltijas valstīs - Igaunijā un Lietuvā, varēja novērot nacionālo atmodu visās tās izpausmēs: cilvēki sāka publiski lietot nacionālo simboliku, arī padomju laikā iznīcinātos savu valstu nacionālos karogus un gérboṇus. Veidojās neatkarības kustības, no kurām Latvijā lielākā neapšaubāmi bija Latvijas Tautas fronte. Vietējā, republiku reǵionālā padomju nomenklatūra, kuras varas leǵitimitāte sakṇojās komunistiskās partijas Maskavas centrālās varas orgānos, bija nopietnas izvēles priekšā, ko tālāk iesākt, - turēties pie vecajām "pārbaudìtajām vērtībām", kas nopietni sāka šḳobīties, vai mainìt "kažoku uz otru pusi", nostājoties pārmaiṇu procesa priekšgalā un tā saglabājot varu. Atbildes uz jaunajiem izaicinājumiem nespēja sniegt nedz centrālie PSRS institūti, nedz arī Valsts drošības komiteja. Republikas padomju nomenklatūra bija spiesta manevrēt, sākumā pieņemot kompromisa lēmumus, bet vēlāk

${ }^{82}$ Druviete, I., Kārkliṇa, A., Kusinšs, G., Pastars, E., Pleps, J. (2014). Satversmes 4. panta komentārs. No: Latvijas Republikas Satversmes komentāri. Ievads. I nodaḷa. Vispārējie noteikumi. Aut. kol. prof. R. Baloža zin. vad. Rīga: Latvijas Vēstnesis, 302.

83 Turpat, 303.

${ }^{84}$ Lēmums par latviešu valodas statusu: Latvijas PSR Augstākās padomes lēmums: 06.10.1988. Valsts valodas komisija. http://www.vvk.lv/index.php?sadala=135\&id=167 
"Valsts valoda Latvijas Republikā ir latviešu valoda" zinātnisko komentāru papildinājums

l̦aujoties straumei, kas aiznesa valsts neatkarības virzienā. Valodas jautājums ir minētā spilgts piemērs. Laikraksts "Padomju Jaunatne" 1988. gada 30. augustā publicēja Latvijas Zinātṇu akadēmijas Valodas un literatūras institūta Latviešu valodas nodaḷas vadītājas Ainas Blinkenas rakstu, kas bija veltits latviešu valodas statusa noteikšanai. ${ }^{85}$ Profesore aicināja lasītājus, kuriem rūp latviešu valodas nākotne, desmit dienu laikā nosūtìt atbalsta vēstules Augstākajai padomei, jo tur izšḳiroties latviešu valodas liktenis. Divu nedēḷu laikā padomju republikas parlaments saṇēma vairāk nekā deviṇus tūkstošus vēstuḷu, ko bija parakstījuši vairāk nekā trīssimt piecdesmit tūkstoši cilvēku! Tas notika gandrīz mēnesi pirms Latvijas Tautas frontes (turpmāk - LTF) dibināšanas kongresa.

1998. gada 6. oktobrī Augstākā padome (turpmāk arī - AP) pieñēma lēmumu par latviešu valodas kā valsts valodas atzīšanu LPSR teritorijā. Lēmumā cita starpā ir teikts, ka:
"[..] latviešu valoda ir atzīstama par republikas valsts valodu. [..] Latvijas PSR Augstākā Padome uzskata, ka šāds viedoklis atbilst ḷeṇiniskās nacionālās politikas principiem un PSKP XIX Vissavienības konferences rezolūcijām, kas paredz visu nacionālo valodu brīvu un vispusīgu funkcionēšanu un attīstību. [..] Republikā līdz šim netika veltīta pienācīga uzmanība tautas garīgo vērtību, tai skaitā latviešu valodas, aizsardzībai. [..] pēdējās desmitgadēs ievērojami samazinājusies latviešu valodas lietošana, sarukušas tās funkcijas."

Lēmums tapa liela sabiedriskā spiediena / pieprasījuma rezultātā, AP sākot konkurēt ar vēl nenodibināto LTF. Lēmumā tika noteikts trīs mēnešu termiṇš (līdz 1989. gada 1. janvārim) attiecīga regulējuma izstrādei. Interesanti, ka Augstākās padomes lēmums tika pien̦emts vien divas dienas pirms LTF dibināšanas kongresa, kurš notika 8. oktobrī. ${ }^{86}$ LTF kongresa lēmums uzkrìtoši - gan pēc stila, gan pēc satura atgādināja AP lēmumā noteikto. Turklāt zīmīgi, ka abos dokumentos identiska bija nostādne krievu valodas lietošanas jautājumā. ${ }^{87}$ Šì tendence - AP konkurēt un apsteigt

85 Blinkena, A. (1988). Par latviešu valodas statusu - esošo un vēlamo. Padomju Jaunatne. 165, 30.08.1988.

${ }^{86}$ Kongresā skanēja emocionāli aicinājumi latviešu valodai piešḳirt valsts valodas statusu. Lūk, divu spilgtāko runu fragmenti. Bijušais leǵionārs, vēlākais politikís Visvaldis Lācis izpelnījās vētrainus aplausus, kad teica: "Latviešu valoda ir vienīgā valsts valoda republikā, tā ir valdošā valoda, kā to uzsvēris Rainis. Un arī lietvedības pamatvaloda. (Aplausi.) [..] Krievu valodai, es uzskatu, nekādas privilēgijas nav vajadzīgas un nav dodamas. Jo pretējā gadījumā tas ir šovinisms. (Aplausi.)" Pazīstamais latviešu kinoaktieris Harijs Liepiṇš kongresā cita starpā savukārt paziṇoja: "Mums piešķīra mūsu valsts valodas statusu. Tas ir labi, kaut arī mēs aplaudējām ar aizlauztu pašcieṇu. Tagad jāizstrādā dzelžains likums par tās aizstāvību, lai mēs to saglabātu uz visiem laikiem, lai man vairs nekad nebūtu jādzird par suṇu un fašistu valodu. Lai manu valodu sargātu stingrs likums. (Aplausi.)" Sk. Latvijas tautas fronte. Gads pirmais. Rìga: Latvijas Tautas fronte, 1989, 77, 188.

${ }^{87}$ LTF kongresā 8. oktobrī tika apstiprināta programma, kuras ceturtajā nodaḷā "Nacionālais jautājums” 4. punkts ḷoti atgādina Augstākās padomes pieṇemtā lēmuma tekstu. Latviešu valodai tiek ierādìta valsts valodas vieta, paredzot izstrādāt speciālu valsts valodas likumu un pieṇemt 
"Valsts valoda Latvijas Republikā ir latviešu valoda" zinātnisko komentāru papildinājums

ārpusparlamenta spēkus - turpinājās arī pēc tam, kad 1990. gadā tika ievēlēta AP ar lielu LTF pārstāvniecību. Tad konkurence notika ar Pilsoṇu kongresu par neatkarības pasludināšanu. ${ }^{88}$

1989. gada 5. maijā Augstākā padome pieņēma LPSR Valodu likumu. ${ }^{89}$ Likumu gatavojot, bija vērojama neticami liela tautas iesaiste un interese. Augstākā padome saṇēma vairāk nekā divdesmit septiṇus tūkstošus priekšlikumu, kurus bija parakstijuši gandrīz trīs simti trīsdesmit divi tūkstoši cilvēku! ${ }^{90}$

Likuma 1. pantā bija rakstìts, ka saskaṇā ar Latvijas PSR Konstitūciju Latvijas PSR valsts valoda ir latviešu valoda, tomēr likuma 17. un 20. pantā bija saglabāta iespēja latviešu tekstu dublēt krievu valodā, piemēram, iestāžu, uzñēmumu un organizāciju nosaukumos vai to zīmogos. Jāteic, ka lielākajās LPSR rūpnīcās un uzṇēmumos strādāja, galvenokārt, no citām padomju republikām iebraukušie cittautieši, un pēc likuma pieņemšanas viṇi varēja neraizēties par latviešu valodas nezināšanu, jo likums piẹ̦āva plašu divvalodību. Likuma 9. pantā noteikts, ka "saziṇā ar pilsoṇiem lieto abām pusēm pieṇemamu valodu", kā arī tas, ka uz "pilsoṇu iesniegumiem un sūdzībām atbild tajā valodā, kurā persona pie tiem griezusies, vai citā, abām pusēm pieṇemamā valodā".

Faktiski LPSR Valodu likumu 1989. gada 5. maija redakcijā nevar uzskatìt likumu, kas Latvijā iedibinātu latviešu valodu par valsts valodu, jo tas piel̦āva plašu divvalodību. Šis likums drīzāk uzskatāms par latviešu valodas saglābšanas pasākumu kopumu, kas "aizsāka ilgstošu valodu hierarhijas maiṇas procesu par labu latviešu valodai" ${ }^{91}$

attiecīgus LPSR Konstitūcijas grozījumus. Šajā LTF programmas punktā vēl bija rakstīts, ka latviešu valodai ir jābūt Latvijas PSR valsts orgānu un iestāžu lietvedības valodai, bet krievu valoda izmantojama kā federatīvo attiecību valoda. Pilsoṇu saskarsmē ar Latvijas PSR valsts orgāniem, uzñēmumiem, iestādēm un organizācijām var izmantot kā latviešu, tā krievu valodu un pēc savas izvēles saṇemt šajās valodās oficiālus dokumentus. Sociālās aprūpes sfērā pilsoṇiem jānodrošina brīva latviešu un krievu valodas izmantošana. LTF 1989. gada 10. jūnijā domes sēdē pieṇemtajā rezolūcijā Latvijas PSR Augstākajai padomei tika prasīts LPSR Konstitūcijas 85. pantu izteikt šādā redakcijā: "Tautas deputātu vēlēšanas ir vispārējas: aktīvās un pasīvās vēlēšanu tiesības ir visiem Latvijas PSR iedzīvotājiem, kas uz vēlēšanu dienu sasnieguši 18 gadu vecumu un nodzīvojuši republikas teritorijā ne mazāk par 10 gadiem. Valsts valodas pārvaldǐšana ir obligāts pasīvo vēlētāju tiesību realizācijas priekšnoteikums." Sk. Latvijas tautas fronte. Gads pirmais. Rīga: Latvijas Tautas fronte, 1989, 213, 257.

${ }^{88}$ Balodis, R., Kārkliṇa, A. (2010). Divdesmit gadi kopš Latvijas Neatkarības deklarācijas: valststiesību attīstības tendences un risinājumi. Jurista Vārds. 17/18, 27.04.2010.

${ }^{89}$ Latvijas Padomju Sociālistiskās Republikas valodu likums: 05.05.1989. Latvijas Padomju Sociālistiskās Republikas Augstākās Padomes un Valdības Ziṇotājs. 20, 18.05.1989. http://valoda. ailab.lv/latval/vidusskolai/VALODA/v9-6.htm

${ }^{90}$ Jundzis, T. (1998). Tiesību reformu loma neatkarības atjaunošanā. No: Blūzma, V., Celle, O., Jundzis, T., Lēbers, D. A., Levits, E., Zīle, L..(1998). Latvijas valsts atjaunošana 1986.-1993. Rīga: LU žurnāla "Latvijas Vēsture" fonds, 156.

91 1988. gadā latviešu valodu atzīst par valsts valodu. 
"Valsts valoda Latvijas Republikā ir latviešu valoda" zinātnisko komentāru papildinājums

Neapšaubāmi, pateicoties šim likumam, būtiski paplašinājās latviešu valodas lietošana. Piemēram, likuma 16. pantā noteikts, ka vietu nosaukumi veidojami un dodami latviešu valodā, u. tml. İpaša loma ierādīta arī latgaliešu izloksnei. ${ }^{92}$ Par lielu sasniegumu tajā laikā jāuzskata likuma preambula, kurā likumdevējs secina, ka valodas lietošana pēdējos gadu desmitos ievērojami samazinājusies un šādu aizsardzību tai var garantēt valsts valodas statuss. Likums sākas ar preambulu, kurā likumdevējs uzsver, ka Latvija ir vienīgā etniskā teritorija pasaulē, kuru apdzīvo latviešu tauta, kuras viens no galvenajiem eksistences un kultūras pastāvēšanas un attīstības priekšnosacījumiem ir latviešu valoda. Šeit jāpiebilst, ka likuma preambula saturēja arī reveransu krievu valodai, kura tika pieminēta kā LPSR otrā "visplašāk lietotā valoda", kas turklāt ir "viena no starpnacionālās saziṇas valodām”.

1992. gada 31. martā LPSR Valodu likums tika grozīts, ${ }^{93}$ un tas darbojās līdz pat 2000. gada 1. septembrim. Lasot 1992. gada likuma grozijumus un iedzilinoties AP stenogrammās, rodas iespaids, ka likumdevējs pārejas laikā pēc neatkarības atjaunošanas ir pieņēmis jaunu likumu, jo būtiski tika mainīta iepriekšèjā likuma redakcijā atzītās krievu valodas loma. ${ }^{94}$ Par "jauna likuma pieñemšanu" runāja deputāti, uzstājoties debatēs, piemēram, Dzintars Ābiḳis, ${ }^{95}$ Oḷegs Ščípcovs un Anatolijs Gorbunovs. ${ }^{96}$ Arī pēc formas grozỉjumi drīzāk atgādina jaunu likumu, jo redakcionāli tika grozīti nevis atsevišḳi panti,

${ }^{92}$ Latvijas Padomju Sociālistiskās Republikas Valodu likuma 15. pants bija šāds: "Latvijas Padomju Sociālistiskajā Republikā ir garantēta latviešu valodas, arī izlokšṇu un latgaliešu rakstu valodas lietošana visās kultūras jomās. Valsts garantē arī lībiešu kultūras saglabāšanu un attīstīšanu lībiešu valodā. Latvijas Padomju Sociālistiskajā Republikā tiek nodrošināta citu nacionālo kultūru attīstīšana dzimtajā valodā."

93 Par grozījumiem un papildinājumiem Latvijas Padomju Sociālistiskas Republikas Valodu likumā: 31.03.1992. Latvijas Republikas Augstākās Padomes un Valdības Ziṇotājs. 15/16, 16.04.1992.

${ }^{94}$ Jauno pieeju vislabāk raksturo 4. panta jaunā redakcija: "Lai realizētu iedzīvotāju valodas izvēles tiesības, visiem valsts varas un valsts pārvaldes institūciju, kā arī iestāžu, uzṇēmumu un organizāciju darbiniekiem ir jāprot un jālieto valsts valoda un citas valodas tādā apjomā, kāds nepieciešams viṇu profesionālo pienākumu veikšanai. Valodu zināšanu apjomu, kāds nepieciešams šiem darbiniekiem, nosaka Latvijas Republikas Ministru Padomes apstiprināts nolikums."

${ }^{95}$ Latvijas Republikas Augstākās padomes 1992. gada 24. marta rīta sēdes stenogramma.

96 To apliecina arī Anatolija Gorbunova teiktais, ka "likums [jaunais] atšķirībā no iepriekšējā tiešām vairs nepiel̦auj nekādu kompromisu" un ka "valsts valodas lietošana ir strikti un viennozīmīgi noteikta šajā likumā. Likums neizslēdz pretrunu starp latviešu un krievu valodu, kas paliks, jo gandrīz puse runā krievu valodā, un pilsētās šī krievvalodīgā vide būs. Bet, atspēkojot apgalvojumu, ka šis likums diskriminē krievu valodā runājošos, es apgalvoju to pašu, ko jau teicu tad, kad pien,ēmām iepriekšējo likumu. Diemžēl situācija ir tāda, ka krievu valodā runājošajiem ir jāuzṇemas papildu grūtības un papildu saistības pret latviešu valodu un latviešu tautu. Jo tieši vai netieši visi tie, kuri nezināja, negribēja zināt, nelietoja vai vienkārši nemācēja latviešu valodu, ir piedalījušies šīs situācijas izveidošanā un rusifikācijā, kura ir notikusi." Sk. Latvijas Republikas Augstākās padomes 1992. gada 24. marta vakara sēdes stenogrammu. 
"Valsts valoda Latvijas Republikā ir latviešu valoda" zinātnisko komentāru papildinājums

bet ar nosaukumu "grozījumi" tika pārjaunots pilnībā viss likums. ${ }^{97}$ N̦emot vērā, ka AP saglabāja sākotnējo tiesību akta nosaukumu, svittrojot vien abreviatūru LPSR, deputāts Indulis Strazdiṇš rosināja nomainìt likuma nosaukumu uz "Par valsts valodu", tomēr viṇa priekšlikums netika atbalstîts. Pret grozijjumiem protestēja krievu valodas aizstāvji, kas pieprasijja sākotnējās likuma redakcijas saglabāšanu, uzskatot, ka atteikšanās no "valodas izvēles" ir nepiel̦aujama un fundamentāla likuma būtỉbas pārveidošana. ${ }^{98}$ Interesanti, ka sēdē attiecībā uz minoritāšu valodu lietošanu no krievu tiesību aizstāvju puses izskanēja aicinājumi sekot pirmskara Valodas likumā ietvertajām kvotām. Tas netika atbalstīts. AP Valodu komisijas priekšsēdētāja Dzintara Ābiḳa ieskatā pirmā neatkarības perioda situācija nav salīdzināma, jo tolaik latvieši nebija minoritāte savā dzimtenē. Viņš aicināja likumdevējiem būt prasīgākiem: "Citādi, ja tagad mēs, latviešu nācija, neaizsargāsim latviešu valodu ar likumu, tad reāli apdzīvotajās vietās, kurās latvieši ir izteikta minoritāte, latviešu valoda neizbēgami ir lemta iznīcībai." ${ }^{99}$ Par spīti deputāta Oḷega Ščipcova aicinājumam atlikt likuma grozijjumu spēkā stāšanos uz gadu, jo tik strauji atsakoties no krievu valodas lietošanas situācija kḷūšot par "sprādzienbīstamu", ${ }^{100}$ parlaments likumu pienēema galīgajā lasijumā. Lìdz ar likuma pien,emšanu, tika izveidota arī Valodas inspekcija, kuras galvenais uzdevums, pēc Ābiḳa vārdiem, bija uzraudzība par Valodu likuma normu ievērošanu reālajā dzīvē, ${ }^{101}$ jo, ja nebūs inspekcijas, tad "būs ārkārtīgi sarežg̀iti ieviest likumu. [..] Protams, tai būtu jābūt nelielai inspekcijai, paredzot arī sabiedrisko inspektoru institūciju." ${ }^{102}$

1995. gada 23. novembrī, pusotru mēnesi pēc 6. Saeimas vēelěšanām, Māra Gaiḷa (partija "Latvijas Cel̦š̀") vadītais Ministru kabinets, kuru bija izveidojusi iepriekšējā 5. Saeima, iesniedza jaunievēlētās Saeimas izskatǐšanai likumprojektu "Latvijas Republikas Valsts valodas likums”. Šādu prioritāti neatrast valdības deklarācijā, ${ }^{103}$ sabiedriskā pie-

97 Šāds risinājums balstījās uz Dzintara Ābiḳa priekšlikumu, kuru balsojumā atbalstīja AP, - "kā redzam, tad lielāki vai mazāki grozījumi ir gandrīz katrā Valodu likuma pantā. [..] es redzu, ka arī deputātiem ir grūtības uztvert šos labojumus kā vienotu likumu. Man ir tāds lūgums - vai nevarētu uz trešo lasījumu labojumus Valodu likumā formulēt tādējādi, ka, respektīvi, mēs sagatavotu Valodu likumu šādā redakcijā un publicētu visus likuma pantus tādus, kādi tie ir pirmajā redakcijā, lai, lasot avīzē, cilvēkiem uzreiz būtu skaidrs, par ko ir runa." Sk. Latvijas Republikas Augstākās padomes 1992. gada 24. marta vakara sēdes stenogrammu. https://www.saeima.lv

${ }^{98}$ Latvijas Republikas Augstākās padomes 1992. gada 24. marta rīta sēdes stenogramma. https:// www.saeima.lv

${ }^{99}$ Latvijas Republikas Augstākās padomes 1992. gada 24. marta rīta sēdes stenogramma. https:// www.saeima.lv

${ }^{100}$ Latvijas Republikas Augstākās padomes 1992. gada 31. marta rīta sēdes stenogramma. https:// www.saeima.lv

${ }^{101}$ Latvijas Republikas Augstākās padomes 1992. gada 24. marta vakara sēdes stenogramma. https:// www.saeima.lv

102 Latvijas Republikas Augstākās padomes 1992. gada 31. marta rīta sēdes stenogramma. https:// www.saeima.lv

103 Ziṇojums par kabineta sastādīšanu un valdības deklarāciju. Latvijas Republikas Ministru kabinets. 08.12.2020. https://www.mk.gov.lv/lv/ministru-kabineta-vesture 
"Valsts valoda Latvijas Republikā ir latviešu valoda" zinātnisko komentāru papildinājums

prasījuma šāda likuma pien̦emšanai nebija. Nopietnas pārdomas raisa arī likumprojekta iesniegšanas datums Saeimā. ${ }^{104}$ Valsts valodas likumprojekts "nogulēja" par to atbildīgajā Izglìtỉbas, kultūras un zinātnes komisijā veselu pusotru gadu. Par likumprojektu sāka izskanēt kritiskas piezīmes. Latvijas Cilvēktiesību un etnisko studiju centra direktora Nila Muižnieka ieskatā vairāki likumprojekta panti bija pretrunā ar Latvijas starptautiskajām saistībām. 1996. gada Latvijas Universitātes Juridiskās fakultātes izdevumā viṇš rakstīja, ka, atjaunojot valsts valodas statusu valsts pārvaldē, sabiedrībā un izglìtibas sistēmā, ir rūpīgi jāseko līdzi, lai latviešu lingvistisko cilvēktiesību veicināšana nenonāktu pretrunā ar citām tiesībām un brīvībām. ${ }^{105}$ Likumprojekts piedzīvoja grūtu likteni un vairākas Saeimas. Pārskatāmības labad vajag izsekot likumprojekta apstiprināšanas gaitai hronologiski.

Pirmais lasījums notika 6. Saeimā 1997. gada 5. jūnijā (pusotru gadu pēc tā iesniegšanas!). Māra Gaiḷa valdība likumprojektu nomainīja ar komisijas izstrādātu alternatīvu likumprojektu, pamatojot šādu rīcību ar to, ka valdības iesniegtajā likumprojektā ir daudz juridisku pretrunu un neprecizitāšu. ${ }^{106}$ Visvairāk tika debatēts par izglītības sadalıu, jo tajā bija paredzēta pilnīga pāreja uz latviešu valodu arodizglītības iestādēs. Jāatzīmē, ka jau pirms pirmā lasījuma bija pilnīgi skaidrs, ka pret nepieciešamību pieņemt jaunu valodas likumu iestāsies Baltijas jūras valstu padome, EDSO un Eiropas Padome, ${ }^{107}$ kā arī Amerikas Savienotās Valstis. ASV vēstnieks Larijs Nepers ḷoti tieši to norādīja Saeimas atbildīgajai komisijai. Viňš nosūtīja vēstuli, kurā apšaubīja jauna likuma pieṇemšanas nepieciešamỉbu un norādỉja: "[..] vismaz ceram, ka Saeima atturēsies pieṇemt šo likumprojektu tā pašreizējā formā." 108

Otrais lasījums notika 6. Saeimā 1998. gada 23. aprīlì. Šai pašã dienā Saeima saṇēma arī ASV vēstnieka Larija Nepera vēstuli, kurā viṇš rakstīja, ka "Amerikas Savienoto Valstu valdība ir norūpējusies par negatīvajām sekām, kādas varētu izraisìt topošā valodas likuma pieṇemšana Saeimā." ${ }^{109}$ ASV vēstnieks pirms tam bija nosūtīisis divas vēstules arī Saeimas

${ }^{104}$ Likumprojektu, kas vēlāk četrus gadus tika vētīts Saeimā, aizejošā “tehniskā valdība” iesniedza 1995. gada 23. novembrī, dienā, kad notika balsojums par Valsts prezidenta izvirzīto apvienības “"Tēvzemei un Brīvībai"/LNNK” Ministru prezidenta Māra Grīnblata kandidatūru. Sk. Balsojums par Māra Grīnblata iesniegto valdības sastāvu. Latvijas Vēstnesis. 183, 24.11.1995. https://www.vestnesis.lv/ ta/id/27707. Jaunievēlētajā Saeimā koalīcijas veidošana notika smagi un bija skaidrs, ka Ministru prezidenta kandidāts nenāks no partijas "Latvijas Ceḷš" rindām. Valsts prezidents Guntis Ulmanis centās atrast tādu Ministru prezidenta amata kandidātu, kurš iegūtu Saeimas vairākuma balsis.

${ }^{105}$ Muižnieks, N. (1996). Aktuāli cilvēktiesību jautājumi Latvijā: praktiḳa vērtējums. Cilvēktiesību Žurnāls. 3, 14.

${ }^{106}$ Latvijas Republikas 6. Saeimas pavasara sesijas 1997. gada 5. jūnija sēdes stenogramma.

${ }^{107}$ No Latvijas Republikas Ārlietu ministrijas valsts sekretāra p. i. A. Vovera 1997. gada 25. septembra vēstules Nr. 42/682-60003 Saeimas Izglītības, kultūras un zinātnes komisijas priekšsēdētājam Dz. Ābiķim. Nepublicēta. Saeimas arhīvs.

108 Amerikas Savienoto Valstu vēstnieka L. Nepera 1998. gada 23. aprīḷa vēstule Saeimas Izglīiības, kultūras un zinātnes komisijas priekšsēdētājam Dz. Ābiḳim. Nepublicēta. Saeimas arhīvs.

${ }^{109}$ Amerikas Savienoto Valstu vēstnieka L. Nepera 1998. gada 23. aprīḷa vēstule Saeimas Izglītības, kultūras un zinātnes komisijas priekšsēdētājam Dz. Ābiḳim. Nepublicēta. Saeimas arhīvs. 
"Valsts valoda Latvijas Republikā ir latviešu valoda" zinātnisko komentāru papildinājums

priekšsēdētājam Alfrēdam Čepānim, uzstājīgi aicinot likumprojekta izskatīšanu sākt tikai pēc Eiropas Padomes un Baltijas jūras valstu padomes atsauksmju saṇemšanas. ${ }^{110}$ Viņš aicināja atlikt otro lasījumu, lai varētu iesniegt papildu priekšlikumu, un izteica cerību, ka viņa viedoklis tiks nnemts vērā. EDSO vispirms iebilda pret to, ka likumprojektā paredzētais privātām organizācijām kārtot jautājumus ar privātpersonām valsts valodā aizskar personas pamattiesības un brīvības. ${ }^{111}$ Starptautiskais spiediens bija ievērojams, un šajās norisēs tika iesaistìta arī Latvijas valdība. Ministru kabinets 1998. gada 15. aprīili ārkārtas sēdē nolēma atbalstìt EDSO rekomendācijas. Ārlietu ministrija vēstulē atbildīgajai komisijai norādīja uz vairākām nepilnībām, paužot uzskatu, ka likumā ietverta nepamatoti plaša valsts iejaukšanās privātajā sfērā, liekot privātiem uzṇēmumiem lietot valsts valodu. ${ }^{112}$ Saeimas sēdes debatēs par likumprojektu politiska spiediena esamību nenoliedz arī atbildīgās komisijas priekšsēdētājs Dzintars Ābiḳis, kurš stāstīja par dienu iepriekš notikušu mēginājumu kārtējo reizi pagarināt priekšlikumu iesniegšanu terminuu lïdz 6. maijam. Ābikis no Saeimas tribīnes sacijja, ka tas "faktiski nozīmētu likumprojekta, tā teikt, nonememšanu no izskatīšanas", 113 jo pavisam tuvu bija 7. Saeimas vēlēšanas. Trešais lasījums 6. Saeimā tā arī nenotika. Likumprojekts šai lasỉjumā ieguva nosaukumu "Valsts valodas likums". Parādijīās doma par Satversmes 4. panta papildināšanu ar valsts valodas klauzulu. ${ }^{114}$

Atgriešanās pie pirmā lasījuma notika 7. Saeimā 1998. gada 10. decembrī, kad jaunievēlētā 7. Saeima, pārvērtējot iepriekšējās Saeimas atstāto likumdošanas "mantojumu", nolēma skatìt Valsts valodas likuma projektu.

Otrais lasijums notika 7. Saeimā 1999. gada 18. martā. Atbildīgās komisijas sēdēs, kā 6., tā 7. Saeimā, bieži dalībnieki bija EDSO eksperti, kas iedziḷinājās, skaidroja un komentēja likumprojekta normas un deputātu priekšlikumus. ${ }^{115}$ Komisija vairākkārt tikās arī ar pašu EDSO komisāru Maksu van der Stūlu.

${ }^{110}$ Amerikas Savienoto Valstu vēstnieka L. Nepera 1998. gada 11. marta vēstule 6. Saeimas priekšsēdētājam A. Čepānim; Amerikas Savienoto Valstu vēstnieka L. Nepera 1998. gada 23. aprịḷa vēstule 6. Saeimas priekšsēdētājam A. Čepānim. Nepublicētas. Saeimas arhīvs.

${ }^{111}$ Eiropas Drošības un sadarbības organizācijas Augstā komisāra nacionālo minoritāšu biroja 1998. gada 23. marta atzinums par Latvijas Republikas Valsts valodas likuma projekta atbilstïbu Latvijas starptautiskajiem pienākumiem un saistībām. Nepublicēts. Saeimas arhīvs.

${ }^{112}$ Latvijas Republikas Ārlietu ministrijas valsts sekretāra p. i. A. Vovera 1997. gada 25. septembra vēstule Nr. 42/682-60003 Saeimas Izglīiības, kultūras un zinātnes komisijas priekšsēdētājam Dz. Ābiḳim. Nepublicēta. Saeimas arhīvs.

113 Turpat.

${ }^{114}$ Latvijas Republikas 6. Saeimas pavasara sesijas 1998. gada 23. aprīla sēdes stenogramma. https:// www.saeima.lv

115 Piemēram, 6. Saeimas Izglītības, kultūras un zinātnes komisijas 1998. gada 25. augusta sēdes protokols Nr. 161; 6. Saeimas Izglìtības, kultūras un zinātnes komisijas 1998. gada 31. marta sēdes protokols Nr. 132; 7. Saeimas Izglītības, kultūras un zinātnes komisijas 1998. gada 31. marta sēdes protokols Nr. 132; 7. Saeimas Izglītības, kultūras un zinātnes komisijas 1999. gada 11. janvāra sēdes protokols Nr. 1. 
"Valsts valoda Latvijas Republikā ir latviešu valoda" zinātnisko komentāru papildinājums

Trešais lasījums 7. Saeimā notika 1999. gada 8. jūlijā. ${ }^{116}$ Pirms šī lasījuma EDSO komisārs vēstulē Saeimai rakstīja, ka nav ņemti vērā EDSO aizrādījumi attiecībā uz valodas likuma iejaukšanos privātajā sfērā. Komisārs EDSO vārdā norādīja, ka privātā sfēra tomēr ir jānodala no valsts sfēras, bet latviešu valodas aizsardzību vajadzētu risināt, neizmatojot likuma noteikumus un tajā paredzētus aizliegumus. Tika piedāvāts strādāt pie latviešu valodas lietošanas veicināšanas, sagatavojot plašu valodas apgūšanas programmu. ${ }^{117}$ Likumprojekts par spīti ievērojamai pretestîbai un politiskam spiedienam tomēr tiek pieņemts trešajā lasījumā.

Valsts prezidente likumu neizsludināja un atgrieza to Saeimā otrreizējai caurlūkošanai. Ārlietu ministrs Indulis Bērziņš darbu pie Valsts valodas likuma izstrādes raksturoja kā "vienu no aktuālākajiem 1999. gada jautājumiem gan iekšpolitikā, gan ārpolitikā". ${ }^{118}$ Patiešām, likumprojekts bija smags pārbaudijums politiskajai elitei, kura nonāca neapskaužamā situācijā. Tā laika sociālajos medijos var lasìt par EDSO komisāra van der Stūla rakstisku vēstuli Valsts prezidentei. ${ }^{119}$ Valsts prezidente Vaira Vīḳe-Freiberga, izmantojot Satversmē noteiktās pilnvaras, likumu atgrieza Saeimai pārstrādāšanai,

116 Visus likuma garā ceḷa pagriezienus ir pārlieku apjomīgi piefiksēt. Šeit, piemēram, viens no tiem. 1999. gada 16. jūnijā vajadzēja notikt likumprojekta trešajam lasījumam, taču Saeima, balstoties uz Saeimas prezidija priekšlikumu, to atlika. İstais iemesls stenogrammās nav lasāms (likumprojekts vēl neesot bijis gatavs trešajam lasījumam, to vēl jāuzlabo), taču patiesais iemesls, protams, bija EDSO iebildumi, par kuriem var lasīt gan tā laika plašsaziṇas līdzekḷos, gan tie atspoguḷoti stenogrammās. Var saprast, ka atbildīgās komisijas vadītājs Dzintars Ābiḳis intensīvi konsultējās ar ekspertiem, lai panāktu kompromisu atsevišḳās Valsts valodas likumprojekta normās. Par to liecina viṇa paša izteikumi debatēs. Piemēram, "komisija izskatīja šo jautājumu, un, n̦emot vērā to, ka tikšanās reizē ar van der Stūla kungu tika panākta vienošanās, ka van der Stūla kungam nebija principiālu iebilžu pret to, ka likumprojekts varētu tikt skatīts otrajā lasījumā, bet tika ierosināts izveidot kopēju darba grupu ar Eiropas drošỉbas un sadarbības organizācijas ekspertiem un rūpīgi piestrādāt pie likumprojekta vēl laika posmā starp otro un trešo lasījumu." Sk. Plamše, K. (1999). EPPA ziṇotāji par Latviju kritiskāki nekā Makss van der Stūls. Diena. 25.06.1999. https:// www.diena.lv/raksts/pasaule/krievija/eppa-zinotaji-par-latviju-kritiskaki-neka-makss-van-derstuls-10472191; Van der Stūlam nav skaidri valodas likuma izpildes noteikumi. Delfi. 09.08.2000. https://www.delfi.lv/news/national/politics/van-der-stulam-nav-skaidri-valodas-likuma-izpildesnoteikumi.d?id=430454; Latvijas Republikas 6. Saeimas pavasara sesijas 1998. gada 23. un 29. aprīla sēžu stenogrammas.

${ }^{117}$ Eiropas Drošỉbas un sadarbības organizācijas augstā komisāra nacionālo minoritāšu jautājumos Maksa van der Stūla 1998. gada 14. augusta vēstule Saeimas Izglītības, kultūras un zinātnes komisijas priekšsēdētājam Dz. Ābiḳim. Nepublicēta. Saeimas arhīvs.

${ }^{118}$ Latvijas Republikas Ārlietu ministra I. Bērziṇa 1999. gada 29. oktobra vēstule Nr. 33/230-7460 Saeimas Izglītības, kultūras un zinātnes komisijas priekšsēdētājam Dz. Ābiḳim. Nepublicēta. Saeimas arhīvs.

119 Valsts prezidente Vaira Vỉḳe-Freiberga saṇēma EDSO komisāra minoritāšu jautājumos Maksa van der Stūla vēstuli. (12.07.1999.). Latvijas V́alsts prezidents [Latvijas Valsts prezidenta mājaslapa]. https://www.president.lv/lv/jaunums/valstsprezidente-vaira-vike-freiberga-sanema-edso-komisaraminoritasu-jautajumosmaksa-van-der-stula-vestuli?utm_source=https\%3A\%2F\%2Fwww.google. com\%2F. 
"Valsts valoda Latvijas Republikā ir latviešu valoda" zinātnisko komentāru papildinājums

iebildes bija gandrīz tādas pašas kā EDSO. Ārlietu ministrs atbildīgajai komisijai rakstija, ka "Latvijas partneriem jābūt pārliecinātiem, ka Valsts valodas likums atbilst politiskajiem dalības kritērijiem. Pilntiesīga dalība Eiropas Savienībā būs viena no svarīgākajām garantijām Latvijas valstiskuma neatgriezeniskumam un tā neatņemamā atribūta - latviešu valodas - attīstībai." 120

Otrreizēja Valsts valodas likuma caurlūkošana. Saeima 1999. gada 9. decembrī, balstoties uz Valsts prezidentes ieteikumiem, likumu precizēja.

Valsts valodas likums tika izsludināts 1999. gada 21. decembrīin un stājās spēkā 2000. gada 1. septembrī; tad spēku zaudēja Latvijas Republikas Valodu likums. Jaunais likums tika dēvēts par secīgu jeb nākamo soli valsts valodas statusa nostiprināšanā, ${ }^{122}$ taču liela prieka par jaunā likuma pieņemšanu nebija. No Saeimas nacionālā spārna politikiiem izskanēja izteikums par "piedegušu biezputru". ${ }^{123}$ Deputātu Egila Baldzēna un Violas Lāzo ieskatā šis likums salīdzinājumā ar 1992. gadā grozìto 1989. gada likumu bija sanācis "krietni maigāks" un pat "vājinot latviešu valodas pozīcijas", līdz ar ko "mazinājusies ir latviešu valodas juridiskās aizsardzības kvalitāte". ${ }^{124}$ Šādam viedoklim nevar nepiekrist, un, lasot stenogrammas, tajās bieži redzams deputātu neviltots sašutums par to, ka kārtējo reizi nav izdevies saglabāt līdzšinējās (1989. gada likuma) redakcijas vairākos pantos. Stratēgiski politiska kḷūda bija šì likuma skatǐšana nepiemērotā laikā, jo starptautisko ekspertu kritiku saṇēma arī 1989. gada likuma regulējums, kurš bija ietverts jaunajā likumprojektā. ${ }^{125}$ Valsts bija kḷuvusi neatkarīga, un ar tautas mandātu apveltìtais likumdevējs bija tiesīgs rīkoties pēc saviem ieskatiem, ${ }^{126}$ tomēr, kad nacionālas valsts

${ }^{120}$ Latvijas Republikas ārlietu ministra I. Bērziṇa 1999. gada 29. oktobra vēstule Nr. 33/230-7460 Saeimas Izglītības, kultūras un zinātnes komisijas priekšsēdētājam Dz. Ābiḳim. Nepublicēta. Saeimas arhīvs.

${ }^{121}$ Valsts valodas likums: LR likums. Latvijas Vēstnesis. 428(433), 21.12.1999.

${ }^{122}$ Druviete, I. (2013). Latviešu valoda pēc neatkarības atgūšanas: valodas situācija un valodas politika. No: Latvieši un Latvija. Akadēmiski raksti. III sējums. Atjaunotā Latvijas valsts. Galv. red. J. Stradiņš. Rīga: Latvijas Zinātṇu akadēmija, 261.

${ }^{123}$ Latvijas Republikas 7. Saeimas rudens sesijas 1999. gada 9. decembra sēdes stenogramma. https:// www.saeima.lv

${ }^{124}$ E. Baldzēns sēdē norādīja, ka pie visa vainīgas esot latviešiem tipiskās īpašības - "vēlme nodrošināties pret visu" un lielā "centība lielvaru priekšā", kas konkrētā gadỉjumā samazināja latviešu valodas juridiskās aizsardzības kvalitāti. Sk. Latvijas Republikas 7. Saeimas rudens sesijas 1999. gada 9. decembra sēdes stenogrammu. https://www.saeima.lv

125 "Latviešu valoda netiek pietiekami lietota uzṇēmumos, bankās, skolās, uz ielām, gimenēs utt. Vēl 1989. gadā pieñemtais likums nav spējis sekmēt vai arī vairs nesekmē latviešu valodas lietošanu Latvijā. Tātad tā ir kvantitatīva problēma. [..] 1989. gadā tika izmantoti valstiskie piespiedu mehānismi un latviešu valoda tika iecelta valsts valodas statusā. [.] Mūsu pieredze pēdējo astoṇu gadu laikā rāda, ka piespiedu kārtā latviešu valodu par dabisku nepieciešamību Latvijas valstī nepadarīsi." Sk. Ziemele, I. (1998). Valodas lietošanas dilemma Latvijā: pienākums un nepieciešamība. Mazākumtiesību rokas grāmata. Cilvēktiesību žurnāls. 7/8, 33.

${ }^{126}$ Latvijas Republikas 6. Saeimas pavasara sesijas 1998. gada 23. aprīḷa sēdes stenogramma. 
"Valsts valoda Latvijas Republikā ir latviešu valoda" zinātnisko komentāru papildinājums

valodas jautājums tika likts vienos svaru kausos ar Latvijas uzṇemto ārpolitikas kursu, realitāte izrādijjās gaužām rūgta. Secinājumam, ka valodas politika ir grūti saskaṇojama ar citiem politikas virzieniem, ir loti liela ticamība, atskatoties uz konkrēto likumdošanas procesu un tā rezultātu. ${ }^{127}$

Vairāku gadu garajā likumprojekta apstiprināšanas laikā visām valdībām to deklarācijās galvenais akcents tika likts uz valsts uzṇemto ārpolitisko kursu, t. i., virzību uz Eiropas Savienību un NATO. Valstij, izvirzot savu lielo stratēgisko mērḳi par dalību ES un NATO, nācās būt "dzirdīgai" pret Rietumu ekspertu padomiem. Šĩ iemesla dēl valsts valodas oponentu ${ }^{128}$ sākotnējais retoriskais jautājums: "Vai mums no valsts puses ir jālien iekšā privātajā sektorā?" beigu beigās pārvērtās par uzstādỉjumu: "Ir jānodala valodas lietošanā valsts sfēra no privātā sektora!"129

Latviešu kā valsts valodas aizstāvji likumdošanas procesā nespēja noturēt stingru pozīciju par latviešu valodas lietošanu privātajā sfērā. Jaunpien,emtais likums sagādāja lielu vilšanos tiem, kas cerēja, ka Latvija spēs nosargāt savu pozīciju valodu jautājumā un realizēt patstāvīgāku politiku. Valodas aizstāvjiem nācās pieņemt, ka, neskatoties uz neatkarīgas, nacionālas valsts pastāvēšanu, tās politika ir cieši saistīta un pat atkarīga no "lielās politikas nospraustās dienaskārtỉbas", 130 un likumdevēja pienākums ir ne tikai formāli, tehniski pildīt likumdevēja pienākumus, bet tam jābūt arī tālredzīgam stratēgim, jāizjūt pareizais laiks konkrētām likumdošanas iniciatīiām.

Ieskatam - atsevišḳi Saeimas deputātu izteikumi no 1999. gada 9. decembra sēdes debatēm par Valsts valodas likumu: ${ }^{131}$

Dzintars Ābiḳis: “Cienījamie kolēǵi! Komisijas vārdā es gribu atgādināt, ka mēs esam iesnieguši vienu likumprojektu, jo, klausoties debatēs, liekas, ka vieni saka: "Likums ir nacionālistisks!", bet otri saka: “Tas absolūti neievēro nacionālās intereses!" Man ir tāda sajūta, ka mēs esam iesnieguši divus likumprojektus."

${ }^{127}$ Druviete, I. (2010). Skatījums. No: Valoda, Sabiedrība, Politika. LU Akadēmiskais apgāds, 80.

128 Jāatzīst, ka valsts valodas oponenti publiski gan runāja par to, ka "valsts valoda ir jāzina visiem Latvijas iedzīvotājiem. Latviešu valodai jāvieno sabiedrība un jāveicina tajā saskaņa. [..] Valsts valoda ir galvenais sabiedrības integrācijas instruments.” Taču tajā pašā laikā norādīja, ka nav pareizi likumprojektā krievu valodas lietošanu izslēgt valsts un pašvaldību iestādēs, tiesās u. tml. Tas radīšot grūtības risināt problēmas cilvēkiem, kas vāji zina valsts valodu, un tādējādi Valsts valodas likums veicinās nevis mūsu sabiedrības integrāciju, bet piespiedu asimilāciju, kā arī negatīvi ietekmēs Latvijas tagadni un nākotni. (Saskaṇā ar Kārtības ruḷ̦a 144. pantu, politisko organizāciju apvienības "Par cilvēka tiesībām vienotā Latvijā" frakcijas paziṇojums par balsošanas motīviem, balsojot par likumprojekta "Valsts valodas likums" pieṇemšanu otrajā lasījumā.) Sk. Latvijas Republikas 7. Saeimas ziemas sesijas 1999. gada 18. marta sēdes stenogrammu. https://www. saeima.lv

${ }^{129}$ Latvijas Republikas 7. Saeimas ziemas sesijas 1999. gada 18. marta sēdes stenogramma. https:// www.saeima.lv

${ }^{130}$ Valsts valodas centra vadītāja Dzintra Hirša: Latviešu valoda okupācijas seku spīlēs. Latvijas Vēstnesis. 406/407, 08.12.1999. https://www.vestnesis.lv/ta/id/14.414.

${ }^{131}$ Latvijas Republikas 7. Saeimas rudens sesijas 1999. gada 9. decembra sēdes stenogramma. 
"Valsts valoda Latvijas Republikā ir latviešu valoda" zinātnisko komentāru papildinājums

Jānis Jurkāns: "Neḷausim nacionālistiskām metastāzēm pārṇemt mūsu likumdošanu!"

Jakovs Pliners: "Strādājot pie likumprojekta, deputātu vairākums nedomāja par gandrīz 900 tūkstošiem Latvijas cittautiešu."

Pēteris Tabūns: "Dažiem latviešiem ir tāda pārcenšanās tieksme - darìt to, ko neprasa, pārcensties un uztaisīt vēl sliktāk pašam priekš sevis."

Juris Dobelis: "Valsts valodas likuma pien,emšanu saistīt ar iestāšanos Eiropas Savienībā ir vienkārši smieklīgi. [..] Tā ir uzspiesta izrunāšanās, jo labi zināms, ka, lielajiem procesiem virzoties uz priekšu, neviens tādas lietas ippaši neievēros."

Rišards Labanovskis: "Latvijā pastāv valodu konkurence. [..] valodai sagaidāmi grūti laiki un tā var izrādīties zaudētāja šajā konkurences cinnā."

Komentāra C daḷas "Valsts valoda" 1. sadaḷā "Valsts valodas statusa atjaunošana un latviešu valodas statusa nostiprināšana Satversmē" pēdējā rindkopā rakstīts: "Satversmes 78. panta kārtībā rīkotajā tautas nobalsošanā Latvijas pilsoṇu kopums ar konstitucionālo balsu vairākumu (Satversmes 79. panta pirmā daḷa) noraidīja priekšlikumu noteikt krievu valodai otras valsts valodas statusu. 2012. gada 18. februārī notikušajā tautas nobalsošanā "Par Satversmes grozijumu pien̦emšanu" balsoja 273347 vēlētāji $(24,88$ \%), bet pret grozijjumu pien̦emšanu Satversmē bija 821722 vēlētāji (74,8 \%)."132

Valodas jautājums izrādỉjās liktenīgs ne tikai Satversmes otrajai pamattiesību daḷai starpkaru periodā, bet arī tautas nobalsošanām otrajā neatkarības periodā. Latvijas Republikas pilsoṇiem 2012. gada 18. februārī tautas nobalsošanā bija jāizšḳiras par otru valsts valodu tā saucamajā "valodas referendumā". Tautas nobalsošana notika par likumprojekta "Grozijumi Latvijas Republikas Satversmē" pien̦emšanu. Likumprojektā bija paredzēts mainīt Satversmes 4., 18., 21., 101. un 104. pantu, iekḷaujot tajos nosacijumu par krievu valodu kā otru valsts valodu, nosakot, ka arī pašvaldībās darba valodas ir latviešu un krievu valoda un ikvienam ir tiesības sanemt informāciju latviešu un krievu valodā. Tautas nobalsošanas zīmē bija jautājums: "Vai jūs esat par likumprojekta "Grozījumi Latvijas Republikas Satversmē" pienemšanu, kas paredz krievu valodai noteikt otras valsts valodas statusu?" Iespējamie atbilžu varianti bija šādi: "par" un "pret". ${ }^{133}$

Referendums parādīja politiskās elites samulsumu. Valsts prezidents Andris Bērziñ̌š demonstratīvi boikotēja referendumu, tā rādot piemēru referendumu neapmeklēt nolūkā "noraut kvorumu", turpretī Saeimas pozīcijas partijas, kas vienlaikus bija arī tā sauktās latviskās partijas, aicināja pilsoṇus piedalïties tautas nobalsošanā ${ }^{134}$ un balsot

132 Druviete, I., Kārkliṇa, A., Kusin̦š, G., Pastars, E., Pleps, J. (2014). Satversmes 4. panta komentārs. No: Latvijas Republikas Satversmes komentāri. Ievads. I nodaḷa. Vispārējie noteikumi. Aut. kol. prof. R. Baloža zin.vad. Rīga: Latvijas Vēstnesis, 305.

133 Par grozījumiem Latvijas Republikas Satversmē (2012). Centrālā vēlēšanu komisija. https://www. cvk.lv/lv/tautas-nobalsosanas/par-grozijumiem-latvijas-republikas-satversme-2012

${ }^{134}$ Prezidents: referendums par valodu nebūs gada svarīgākais notikums. Tvnet. 20.12.2011. https:// www.tvnet.lv/4739059/prezidents-referendums-par-valodu-nebus-gada-svarigakais-notikums 
"Valsts valoda Latvijas Republikā ir latviešu valoda" zinātnisko komentāru papildinājums

pret krievu valodu kā otru valsts valodu. 2012. gada valodas referenduma sekas bija "Satversmes kodola koncepcijas" radīšana, ko paveica Egila Levita vadītā Valsts prezidenta Konstitucionālo tiesību komisija, ${ }^{135}$ bet Saeima pienēema Grozìjumus likumā "Par tautas nobalsošanu, likumu ierosināšanu un Eiropas pilsoṇu iniciatīvu”. ${ }^{136}$ Šie grozijumi, bez visa cita, likuma 22. pantā noteiktos 10000 balsstiesīgos Latvijas pilsoṇus, kuriem bija tiesības iesniegt Centrālajā vēlēšanu komisijā likumprojektu, nomainīja pret algoritmu "viena desmitā daḷa vēètāju", kas bija apmēram 150000 balsstiesīgie Latvijas pilsoṇi. ${ }^{137}$ Kopš šiem grozijumiem tautas nobalsošanas vairs nav notikušas. Tas liek pievienoties ekspertu viedoklim, ka pēc Satversmes groziš̌anas referenduma jautājumā tautas nobalsošana kḷūst vien par teorētisku iespējamību. ${ }^{138}$ Valodas referendums, tā radītā situācija un sekas labi sasaucas ar pavisam neseno Ukrainas Konstitucionālās tiesas secinājumu, ka valsts valodas aizsardzība ierindojama nacionālo drošības jautājumu lokā. ${ }^{139}$

Minētā sakarā arī ir vērts piebilst, ka citas Latvijas kaimiṇvalsts - Lietuvas Konstitucionālā tiesa ir atzinusi, ka valsts valoda ir valsts suverenitātes izpausme, kas atklāj valsts integritāti un nedalāmību. ${ }^{140}$

\section{Secinājumi}

Valsts valodai nemainīgi ir jābūt valsts, konkrēti Valsts prezidenta, Saeimas un valdības, prioritāšu lokā. Tikai cienot sevi, savu valodu un valsti, spēsim pacelt savu nacionālo pašapziṇu. Latviskumā stipriem esot, būsim spēka avots arī mazākumtautībām, veidojot piederību Latvijas valstij. ${ }^{141}$ No šì gada (2021) Latvijā ir jauna atzīmējamā diena - Valsts valodas diena. Likumā "Par svētku, atceres un atzīmējamām dienām",

${ }^{135}$ Konstitucionālo tiesību komisija: Viedoklis par Latvijas valsts konstitucionālajiem pamatiem un neaizskaramo Satversmes kodolu. 2012. Rīga: Latvijas Vēstnesis, 17.09.2012.

136 Grozījumi likumā "Par tautas nobalsošanu, likumu ierosināšanu un Eiropas pilsoṇu iniciatīvu": 08.11. 2012. Latvijas Vēstnesis, 186, 27.11.2012.

137 N̦ikona, L. (2021). Vai Latvijā ir iespējams sarīkot iedzīvotāju iniciētu referendumu? LV. 31.08.2021. https://lvportals.lv/viedokli/331821-vai-latvija-ir-iespejams-sarikot-iedzivotaju-inicietu-referendumu-2021?fbclid=IwAR3AnKtRn4HoM_QvMae3_8344ttxkn3eHMsJFEeCXPjmBr9EMUjIpBv wxfJ0

138 Balodis, R. (2021). Par tautas tiesībām un faktiskām iespējām grozìt Latvijas Republikas Satversmi. Tiesības un tiesiskā vide mainīgos apstākḷos. No: Latvijas Universitātes 79. starptautiskās zinātniskās konferences rakstu krājums. Rīga: LU Akadēmiskais apgāds, 416-417. https://www.apgads. lu.lv/fileadmin/user_upload/lu_portal/apgads/PDF/Juridiskas-konferences/JUZK-79-2021/ juzk.79.46_sBalodis.pdf

${ }^{139}$ Ukrainas Konstitucionālās tiesas 2021. gada 14. jūlija spriedums lietā Nr. 1-p/2021. Gov.ua. https:// zakon.rada.gov.ua/laws/show/v001p710-21\#Text

${ }^{140}$ Lietuvas Konstitucionālās tiesas 2006. gada 10. maija spriedums lietā Nr. 25/03, secinājuma 4. punkts.

${ }^{141}$ Balodis, R. (2021). Pārdomas Valsts valodas dienas gaidās. Telos. https://telos.lv/pardomas-valstsvalodas-diena/ 
"Valsts valoda Latvijas Republikā ir latviešu valoda" zinātnisko komentāru papildinājums

pateicoties Valsts prezidenta Egila Levita iniciatìvai, par Vasts valodas dienu ir noteikts 15. oktobris. ${ }^{142}$ Iniciatīvas autora ieskatā tieši šis datums vislabāk akcentēs latviešu valodas kā vienīgās valsts valodas simbolisko un konstitucionālo vērtību Latvijas valsts iekārtā, kā arī vienlaikus stiprinās valodas pozīcijas un veicinās modernas, atvērtas latvietības koncepcijas iedzīvināšanu, sekmēs mazākumtautību iesaisti. ${ }^{143}$ Valsts valoda ir latviešu nācijas saistošais elements. Tilts, kas saista iepriekšejjās paaudzes ar nākamajām un ārpus Latvijas robežām dzīvojošos, latvju tautai piederīgos ar dzimtenē dzīvojošiem tautiešiem. Tas, ka Latvijā valsts valoda ir latviešu valoda, ir pašsaprotami, tomēr vienmēr jāatceras, ka tā nav dāvināta, bet izcīnìta nacionāla vērtība, par kuru jāturpina būt modriem un pastāvīgi jārūpējas. Priekšlikums, pareizāk, aicinājums, ko nesen izvirzīja Valsts prezidents Egils Levits, par atbildīgo Ministru kabineta locekḷu ikgadēju ziņojumu Saeimas sēdē par valsts valodas situāciju un iecerētajiem darbiem šajā jomā ir atbalstāms, tāpat kā doma, ka šim ziṇojumam par valsts valodas situāciju jākḷūst par nozīmīgu parlamentārās diskusijas elementu, tā veicinot Saeimas iesaisti valsts valodas politikas formulēšanā un sabiedrības līdzdalību tajā. ${ }^{144}$ Vai Saeima kārtējo reizi šo ierosinājumu, tāpat kā daudzus citus vērtīgus valsts prezidentu ierosinājumus, neatstās novārtā, redzēsim jau pavisam drīz - 2022. gada 15. oktobrī, kas interesantā kārtā iekrīt jau pēc 14. Saeimas vēlēšanām.

\section{Avoti un literatūra}

\section{Tiesību akti}

1. Grozījumi likumā "Par svētku, atceres un atzīmējamām dienām": Latvijas Republikas likums. Latvijas Vēstnesis. 118, 19.06.2021. https://likumi.lv/ta/id/324120-grozijumi-likuma-par-svetkuatceres-un-atzimejamam-dienam

2. Grozījumi likumā "Par tautas nobalsošanu, likumu ierosināšanu un Eiropas pilsoṇu iniciatīvu": Latvijas Republikas likums. Latvijas Vēstnesis. 186, 27.11.2012. https://likumi.lv/ta/id/58065par-tautas-nobalsosanu-likumu-ierosinasanu-un-eiropas-pilsonu-iniciativu

3. Valsts valodas likums: LR likums. Latvijas Vēstnesis. 428(433), 21.12.1999. https://likumi.lv/ta/ id/14740-valsts-valodas-likums

\section{Vèsturiski tiesību akti}

4. Latvijas Padomju Sociālistiskās Republikas Augstākās padomes lēmums par latviešu valodas statusu: 06.10.1988. http://www.vvk.lv/index.php?sadala=135\&id=167

142 Grozījumi likumā "Par svētku, atceres un atzīmējamām dienām”: LR likums: 16.06.2021. Latvijas Vèstnesis. 118, 03.07.2021.

${ }^{143}$ Latvijas Valsts prezidenta Egila Levita 2019. gada 1. oktobra vēstule Nr. 212 Saeimas Cilvēktiesību un sabiedrisko lietu komisijai. Nepublicēta. Saeimas arhīvs; Valsts prezidenta Egila Levita 2021. gada 5. maija paziñojums Nr. 11. Latvijas Vèstnesis. 84 B, 05.05.2021.

${ }^{144}$ Levits, E. (2021). Egils Levits: 15. oktobris - mūsu valsts valodas diena. Delfi. 15.10.2021. https:// www.delfi.lv/news/versijas/egils-levits-15-oktobris-musu-valsts-valodas-diena.d?id=53681383\&f bclid=IwAR2WmbywM56vA7TaUzy5rRCMJ-ySdRkCuwrZJmfzzp0mxTYORGIcPNajKow 


\section{Ringolds Balodis. Latvijas Republikas Satversmes 4. panta pirmā teikuma \\ "Valsts valoda Latvijas Republikā ir latviešu valoda" zinātnisko komentāru papildinājums}

5. Latvijas Padomju Sociālistiskās Republikas valodu likums: 05.05.1989. Latvijas Padomju Sociālistiskās Republikas Augstākās Padomes un Valdības Ziṇotājs. 20, 18.05.1989. http://valoda. ailab.lv/latval/vidusskolai/VALODA/v9-6.htm

6. Latvijas Tautas Padomes kārtības rullis: LV likums: 23.08.1919. Likumu un Valdības Rīkojumu Kräjums. 11, 1919. https://tzpi.lu.lv/likumdeveja-kartibas-rullis/

7. Likums par Latvijas izglītības iestādēm: 08.12.1919. Likumu un Valdības Rīkojumu Krājums. 13, 31.12.1919. http://periodika.lv/periodika2-viewer/?lang=fr\#panel:pa|issue:354805|article: DIVL50|query:Latvijas\%20Likums\%20par\%20izglitibas\%20iest\%C4\%81des\%20

8. Likums par sapulcēm: 18.07.1923. Valdïbas Vēstnesis. 152, 18.07.1923.

9. Likums par valsts valodu: 05.01.1935. Valdības Vēstnesis. 7, 09.01.1935.

10. Likums par virsnieku un kara ierēdṇu pārbaudīšanu valsts valodas prašanā: LR likums: 17.11.1924. Valdības Vēstnesis. 262, 22.11.1924.

11. Noteikumi par ierēdnuu iecelšanu Latgalē: 26.07.1921. Valdības Vēstnesis. 174, 06.08.1921.

12. Noteikumi par ierēdṇu pārbaudīšanu valsts valodas prašanā: 22.11.1921. Valdības Vēstnesis. 269, 28.11.1921.

13. Noteikumi par Latgales apgabaltiesas vecākā notara darbības atjaunošanu attiecībā uz aktu apstiprināšanu (izdoti Latvijas Republikas Satversmes 81. panta kārtībā): 04.10.1923. Valdības Vèstnesis. 222, 08.10.1923.

14. Noteikumi par Latgales lietu pārzināšanu: 30.06.1921. Valdības Vēstnesis. 177, 10.08.1921.

15. Noteikumi par latgaliešu izloksnes lietošanu: 11.08.1921. Valdības Vēstnesis. 183, 17.08.1921.

16. Noteikumi par valsts valodu (izdoti Latvijas Republikas Satversmes 81. panta kārtībā): 18.02.1932. Valdības Vēstnesis. 39, 18.02.1932.

17. Par grozījumiem un papildinājumiem Latvijas Padomju Sociālistiskas Republikas Valodu likumā: LR likums: 31.03.1992. Latvijas Republikas Augstākās Padomes un Valdības Ziñotājs. 15/16, 16.04.1992. https://likumi.lv/ta/id/65484-par-grozijumiem-un-papildinajumiem-latvijas-padomju-socialistiskas-republikas-valodu-likuma

18. Par mazākuma tautību skolu iekārtu Latvijā: LR likums: 08.12.1919. Likumu un Valdības Rìkojumu Kräjums. 13, 31.12.1919.

19. Par Latvijas tiesām un tiesāšanās kārtību: Tautas padomes pagaidu nolikums. Pagaidu Valdības Vèstnesis. 14.(1.)12.1918.; Latvijas Pagaidu Valdības Likumu un Rīkojumu Kräjums. 1, 15.07.1919.

20. Par Latvijas tiesām un tiesāšanās kārtību: Tautas padomes pagaidu nolikums. Latvijas Pagaidu Valdības Likumu un Rìkojumu Krājums. 1, 15.07.1919.

21. Pārgrozījumi un papildinājumi noteikumos par valsts valodu: 14.06.1934. Valdības Vēstnesis. 132, 16.06.1934.

22. Saeimas kārtības rullis 26.03.1923. Valdības Vēstnesis. 65, 27.03.1923. Tiesību zinātṇu pētniecības institūts. Likumdevēja kārtības rullis. Tiesību zinātn̦u pētniecības institūts (lu.lv).

23. Saeimas kārtības rullis: 20.03.1929. Valdības Vēstnesis. 79, 10.04.1929. Tiesību zinātṇu pētniecības institūts. Likumdevēja kārtības rullis. Tiesību zinātṇu pētniecības institūts (lu.lv)

24. Tautas padomes politiskā platforma: 17.11.1918. Valdības Vēstnesis. 1, 14.12.1918.

\section{Judikatūra}

25. Lietuvas Konstitucionālās tiesas 2006. gada 10. maija spriedums lietā Nr. 25/03.

26. Satversmes tiesas 2005. gada 16. decembra spriedums lietā Nr. 2005-12-0103.

27. Satversmes tiesas 2012. gada 1. novembra spriedums lietā Nr. 2012-06-01.

28. Satversmes tiesas 2015. gada 2. jūlija spriedums lietā Nr. 2015-01-01. 


\section{Ringolds Balodis. Latvijas Republikas Satversmes 4. panta pirmā teikuma \\ "Valsts valoda Latvijas Republikā ir latviešu valoda" zinātnisko komentāru papildinājums}

29. Ukrainas Konstitucionālās tiesas 2021. gada 14. jūlija spriedums lietā Nr. 1-p/2021. Gov.ua. https://zakon.rada.gov.ua/laws/show/v001p710-21\#Text

\section{Protokoli}

30. Satversmes komisijas 1921. gada 3. novembra sēdes protokols Nr. 58. https://tzpi.lu.lv/satversmessapulces-komisijas-sezu-protokoli/

31. Satversmes komisijas 1922. gada 8. jūlija sēdes protokols Nr. 70. https://tzpi.lu.lv/satversmessapulces-komisijas-sezu-protokoli/

32. Satversmes komisijas 1922. gada 14. jūlija sēdes protokols Nr. 77. https://tzpi.lu.lv/satversmessapulces-komisijas-sezu-protokoli/

33. 6. Saeimas Izglītības, kultūras un zinātnes komisijas 1998. gada 25. augusta sēdes protokols Nr. 161. Saeimas arhīvs.

34. 6. Saeimas Izglïtības, kultūras un zinātnes komisijas 1998. gada 31. marta sēdes protokols Nr. 132. Saeimas arhīvs.

35. 7. Saeimas Izglīīibas, kultūras un zinātnes komisijas 1998. gada 31. marta sēdes protokols Nr. 132. Saeimas arhīvs.

36. 7. Saeimas Izglītības, kultūras un zinātnes komisijas 1999. gada 11. janvāra sēdes protokols Nr. 1. Saeimas arhīvs.

\section{Stenogrammas}

37. Latvijas Satversmes sapulces 4. sesijas 7. sēdes 1921. gada 4. oktobrī stenogramma. No: Latvijas Satversmes sapulces stenogrammu izvilkums (1920-1922). Latvijas Republikas Satversmes projekta apspriešana un apstiprināšana. Rīga: Tiesu namu ağentūra, 2006.

38. Latvijas Satversmes sapulces 4. sesijas 8. sēdes 1921. gada 5. oktobrī stenogramma. No: Latvijas Satversmes sapulces stenogrammu izvilkums (1920-1922). Latvijas Republikas Satversmes projekta apspriešana un apstiprināšana. Rīga: Tiesu namu aǵentūra, 2006.

39. Latvijas Satversmes sapulces 5. sesijas 34. sēdes 1922. gada 5. aprīlī stenogramma. Iegūts no: https://tzpi.lu.lv/pirmais-neatkaribas-laiks/saeimas-stenogrammas/

40. Latvijas Republikas 3. Saeimas 2. sesijas 6. sēdes 1929. gada 8. februārī stenogramma. https://tzpi.lu.lv/pirmais-neatkaribas-laiks/saeimas-stenogrammas/

41. Latvijas Republikas 3. Saeimas 8. sesijas 1. sēdes 1931. gada 20. janvārī stenogramma. https://zpi.lu.lv/pirmais-neatkaribas-laiks/saeimas-stenogrammas/

42. Latvijas Republikas 4. Saeimas 2. sesijas 2. sēdes 1932. gada 23. februārī stenogramma. https://tzpi.lu.lv/pirmais-neatkaribas-laiks/saeimas-stenogrammas/

43. Latvijas Republikas Augstākās padomes 1992. gada 24. marta rīta sēdes stenogramma. https://www.saeima.lv

44. Latvijas Republikas Augstākās padomes 1992. gada 24. marta vakara sēdes stenogramma. https://www.saeima.lv

45. Latvijas Republikas Augstākās padomes 1992. gada 31. marta rīta sēdes stenogramma. https://www.saeima.lv

46. Latvijas Republikas 6. Saeimas pavasara sesijas 1997. gada 5. jūnija sēdes stenogramma. https://www.saeima.lv

47. Latvijas Republikas 6. Saeimas pavasara sesijas 1998. gada 23. aprīḷa sēdes stenogramma. https://www.saeima.lv

48. Latvijas Republikas 6. Saeimas pavasara sesijas 1998. gada 29. aprīla sēdes stenogramma. https://www.saeima.lv 
"Valsts valoda Latvijas Republikā ir latviešu valoda" zinātnisko komentāru papildinājums

49. Latvijas Republikas 7. Saeimas rudens sesijas 1999. gada 9. decembra sēdes stenogramma. https://www.saeima.lv

50. Latvijas Republikas 7. Saeimas ziemas sesijas 1999. gada 18. marta sēdes stenogramma. https://www.saeima.lv

51. Tautas padomes 4. sesijas 8. sēdes 1919. gada 27. augustā stenogramma.

\section{Sarakste}

52. Amerikas Savienoto Valstu vēstnieka L. Nepera 1998. gada 11. marta vēstule 6. Saeimas priekšsēdētājam A. Čepānim. Saeimas arhīvs.

53. Amerikas Savienoto Valstu vēstnieka L. Nepera 1998. gada 23. aprīḷa vēstule 6. Saeimas priekšsēdētājam A. Čepānim. Saeimas arhīvs.

54. Amerikas Savienoto Valstu vēstnieka L. Nepera 1998. gada 23. aprīḷa vēstule Saeimas Izglītības, kultūras un zinātnes komisijas priekšsēdētājam Dz. Ābiḳim. Saeimas arhīvs.

55. Eiropas Drošības un sadarbības organizācijas Augstā komisāra nacionālo minoritāšu biroja 1998. gada 23. marta atzinums par Latvijas Republikas Valsts valodas likuma projekta atbilstîbu Latvijas starptautiskajiem pienākumiem un saistībām. Saeimas arhīvs.

56. Eiropas Drošības un sadarbības organizācijas augstā komisāra nacionālo minoritāšu jautājumos Maksa van der Stūla 1998. gada 14. augusta vēstule Saeimas Izglītības, kultūras un zinātnes komisijas priekšsēdētājam Dz Ābiḳim. Saeimas arhīvs.

57. Latvijas Republikas ārlietu ministra I. Bērziṇa 1999. gada 29. oktobra vēstule Nr. 33/230-7460 Saeimas Izglītības, kultūras un zinātnes komisijas priekšsēdētājam Dz. Ābiḳim. Saeimas arhīvs.

58. Latvijas Republikas Ārlietu ministrijas valsts sekretāra p. i. A. Vovera 1997. gada 25. septembra vēstule Nr. 42/682-60003 Saeimas Izglītības, kultūras un zinātnes komisijas priekšsēdētājam Dz. Ābikim. Saeimas arhīvs.

59. Latvijas Valsts prezidenta Egila Levita 2019. gada 1. oktobra vēstule Nr. 212 Saeimas Cilvēktiesību un sabiedrisko lietu komisijai. Saeimas arhivvs.

\section{Literatūra}

60. Balodis, R. (2021). Kā cīṇa par latgaliešu valodu ietekmēja latviešu valodas statusu. Jurista Vārds. $38,21.09 .2021$.

61. Balodis, R. (2020). Līdz ar Satversmes II nodaḷas komentāru izdošanu noslēdzies Satversmes zinātnisko komentāru projekts. Jurista Vārds. 36, 08.09.2020.

62. Balodis, R. (2021). Par nepieciešamību valsts valodai atrast politisku aizbildni. Jurista Vārds. $42,19.10 .2021$.

63. Balodis, R. (2021). Par tautas tiesībām un faktiskām iespējām grozīt Latvijas Republikas Satversmi. Tiesības un tiesiskā vide mainīgos apstākḷos. Latvijas Universitātes 79. starptautiskās zinātniskās konferences rakstu krājums. Rīga: LU Akadēmiskais apgāds.

64. Balodis, R. (2011). Satversmes 99. panta komentārs. No: Latvijas Republikas Satversmes komentāri. VIII nodaḷa. Cilvēka pamattiesības. Zin.vad. R. Balodis. Rīga: Latvijas Vēstnesis.

65. Balodis, R., Kārkliṇa, A. (2010). Divdesmit gadi kopš Latvijas Neatkarības deklarācijas: valststiesību attīstības tendences un risinājumi. Jurista Vārds. 17/18, 27.04.2010.

66. Blinkena, A. (1988). Par latviešu valodas statusu - esošo un vēlamo. Padomju Jaunatne. 165, 30.08.1988.

67. Druviete, I. (2013). Latviešu valoda pēc neatkarības atgūšanas: valodas situācija un valodas politika. No: Latvieši un Latvija. Akadēmiski raksti. 3. sēj. Atjaunotā Latvijas valsts. Galv. red. J. Stradiṇš. Rīga: Latvijas Zinātṇu akadēmija. 


\section{Ringolds Balodis. Latvijas Republikas Satversmes 4. panta pirmā teikuma \\ "Valsts valoda Latvijas Republikā ir latviešu valoda" zinātnisko komentāru papildinājums}

68. Druviete, I. (1998). Latvijas valodu politika Eiropas Savienības kontekstā. Rīga: LU Latviešu valodas institūts, LZA Ekonomikas institūts.

69. Druviete, I. (2010). Skatījums: valoda, sabiedrība, politika. LU Akadēmiskais apgāds.

70. Druviete, I., Kārkliṇa, A., Kusiņš, G., Pastars, E., Pleps, J. (2014). Satversmes 4. panta komentārs. No: Latvijas Republikas Satversmes komentāri. Ievads. I nodaḷa. Vispārējie noteikumi. Zin. vad. R. Balodis. Rīga: Latvijas Vēstnesis.

71. Dupate, K. Reine, I. (2011). Satversmes 110. panta komentārs. No: Latvijas Republikas Satversmes komentāri. VIII nodaḷa. Cilvēka pamattiesības. Zin.vad. R. Balodis. Rīga: Latvijas Vēstnesis.

72. Gehtmane-Hofmane, I. (2021). Satversmes komentāri - zinātnisks traktāts ar praktisku pielietojamu. Zinātṇu Vēstnesis. 3, 29.03.2021.

73. Hirša, Dz. (1999). Latviešu valoda okupācijas seku spīlēs. Latvijas Vēstnesis. 406/407, 08.12.1999.

74. Jundzis, T. (1998). Tiesību reformu loma neatkarības atjaunošanā. No: Blūzma, V., Celle O., Jundzis, T., Lēbers, D. A., Levits, E., Zīle, L. Latvijas valsts atjaunošana 1986.-1993. Rīga: LU žurnāla "Latvijas Vēsture" fonds.

75. Klīve, Ā. (1969). Brīvā Latvija: Latvijas tapšana: atmiṇas, vērojumi un atzinumi. Bruklina: Grāmatu draugs.

76. Krūmiṇa, V. (2013). Ievads Latvijas Republikas Satversmes VI nodaḷas komentāram: tiesu varas evolūcija Latvijā. No: Latvijas Republikas Satversmes komentāri. VI nodaḷa. Tiesa. VII nodaḷa. Valsts kontrole. Zin.vad. R. Balodis. Rīga: Latvijas Vēstnesis.

77. Kusiňš, G. (2020). Satversmes 15. panta komentārs. No: Latvijas Republikas Satversmes komentāri. II nodaḷa. Saeima. Zin.vad. R. Balodis. Rīga: Latvijas Vēstnesis.

78. Latvijas tautas fronte. Gads pirmais. (1989). Rīga: Latvijas Tautas fronte.

79. Lazdiṇš, J. (2014). Rechtspolitische Besonderheiten bei der Entstehung des lettischen Staates und seiner Verfassung. Law, 7.

80. Levits, E. (2021). Egils Levits: 15. oktobris - mūsu valsts valodas diena. Delfi. 15.10.2021. https:// www.delfi.lv/news/versijas/egils-levits-15-oktobris-musu-valsts-valodas-diena.d?id=53681383 \&fbclid=IwAR2WmbywM56vA7TaUzy5rRCMJ-ySdRkCuwrZJmfzzp0mxTYORGIcPNajKow

81. Levits, E. (2019). Valstsgriba. Idejas un domas Latvijai 1985-2018. Rīga: Latvijas Vēstnesis.

82. Matule, S. (2014). Satversmes komentāros padziḷināti izvērsti arī valsts pamati. Jurista Vārds. 46, 08.09.2014.

83. Muižnieks, N. (1996). Aktuāli cilvēktiesību jautājumi Latvijā: praktiḳa vērtējums. Cilvēktiesību Žurnāls. 3. Rīga: Latvijas Universitātes Juridiskās fakultātes Cilvēktiesību institūts.

84. N̦ikona, L. (2021). Vai Latvijā ir iespējams sarīkot iedzīvotāju iniciētu referendumu? LV.31.08.2021. https://lvportals.lv/viedokli/331821-vai-latvija-ir-iespejams-sarikot-iedzivotaju-inicietu-referendumu-2021?fbclid=IwAR3AnKtRn4HoM_QvMae3_8344txkn3eHMsJFEeCXPjmBr9EMUjIpB vwxfJ0.

85. Paegle, S. (1939). Kā Latvijas valsts tapa. Otrais izd. Rīga: Liepājas Burtnieks.

86. Plamše, K. (1999). EPPA zin̦otāji par Latviju kritiskāki nekā Makss van der Stūls. Diena. 25.06.1999. https://www.diena.lv/raksts/pasaule/krievija/eppa-zinotaji-par-latviju-kritiskaki-neka-makssvan-der-stuls-10472191

87. Pleps, J. (2020). Satversmes 21. panta komentārs. No: Latvijas Republikas Satversmes komentāri. II nodal̦a. Saeima. Zin. vad. R. Balodis. Rīga: Latvijas Vēstnesis.

88. Pleps, J. (2021). Vēstures nozīme tiesībnieka darbā. Jurista Vārds. 32, 10.08.2021.

89. Prezidents: referendums par valodu nebūs gada svarīgākais notikums. Tvnet. 20.12.2011. https:// www.tvnet.lv/4739059/prezidents-referendums-par-valodu-nebus-gada-svarigakais-notikums 
90. Skujenieks, M. (1925). Otrā tautas skaitīšana Latvijā. Rīga.

91. Smiltēna, A. (2016). Deleǵétas likumdošanas pirmsākumi Eiropā un Latvijā: promocijas darbs. Rìga: Latvijas Universitāte.

92. Sosāre, M. (1992). Valodu likumdošanas jautājumi Latvijas Republikas pastāvēšanas sākuma posmā. Latvijas Zinātṇu Akadēmijas Vēstis. A daḷa, 4, 01.04.1992.

93. Valoda. 1988. gadā latviešu valodu atzīst par valsts valodu. Providus. 03.01.2012.

94. Van der Stūlam nav skaidri valodas likuma izpildes noteikumi. Delfi. 09.08.2000. https://www. delfi.lv/news/national/politics/van-der-stulam-nav-skaidri-valodas-likuma-izpildes-noteikumi.d?id=430454

95. Ziemele, I. (1998). Valodas lietošanas dilemma Latvijā: pienākums un nepieciešamība. Mazākumtiesību rokasgrāmata. Cilvēktiesību Žurnāls. 7/8. Rīga: Latvijas Universitātes Juridiskās fakultātes Cilvēktiesību institūts.

\section{Citi materiāli}

96. Jaunas Latvijas valdības gaidī̌̌anas laiks turpinās: Balsojums par Māra Grīnblata iesniegto valdības sastāvu. Latvijas Vēstnesis. 183, 24.11.1995. https://www.vestnesis.lv/ta/id/27707

97. Konstitucionālo tiesību komisija: Viedoklis par Latvijas valsts konstitucionālajiem pamatiem un neaizskaramo Satversmes kodolu. 2012. Rīga: Latvijas Vēstnesis, 17.09.2012.

98. Latvijas Universitātes Satversme: 27.04.1923. 3. punkts. Valdības Vēstnesis. 66, 28.03.1923.

99. Ministru kabineta vēsture: Ziṇojums par kabineta sastādīšanu un valdības deklarāciju. Latvijas Republikas Ministru kabinets. 08.12.2020. https://www.mk.gov.lv/lv/ministru-kabineta-vesture

100. Par grozījumiem Latvijas Republikas Satversmē (2012). Centrālà vēlēšanu komisija. 05.03.2012. https://www.cvk.lv/lv/tautas-nobalsosanas/par-grozijumiem-latvijas-republikas-satversme-2012

101. Satversmes tiesas tiesneša Alda Laviṇa atsevišḳās domas lietā Nr. 2019-33-01 "Par Darba likuma 155. panta pirmās daḷas atbilstỉbu Latvijas Republikas Satversmes 110. panta pirmajam teikumam".

102. Valsts prezidenta Egila Levita 2021. gada 5. maija paziṇojums Nr. 11. Latvijas Vēstnesis. 84 B, 05.05.2021.

103. Valsts prezidente Vaira Vīḳe-Freiberga saṇēma EDSO komisāra minoritāšu jautājumos Maksa van der Stūla vēstuli. (12.07. 1999.). Latvijas Valsts prezidents [LV prezidenta mājaslapa]. https:// www.president.lv/lv/jaunums/valstsprezidente-vaira-vike-freiberga-sanema-edso-komisara-minoritasu-jautajumosmaksa-van-der-stula-vestuli?utm_source=https\%3A\%2F\%2Fwww.google. com\%2F 